Volume 12(1), 2018

Page: 1-32

\title{
Design the Roadmap of Holistic Financial Inclusion for Baitul Maal wat Tamwil
}

\author{
Ascarya $^{1}$, Siti Rahmawati², Hendri Tanjung ${ }^{3}$
}

\begin{abstract}
This paper aims to design the roadmap of Holistic Financial Inclusion (HFI) by Baitul Maal wat Tamwil (BMT), where Baitul Maal carries out social inclusion and Baitut Tamwil carries out financial inclusion, using Analysis Network Process (ANP). The results show that the most important aspects of HFI are Sustainability, Development Program, Financing Program and Islamic Microfinance Services, while the most important elements of HFI are regular meeting, micro savings, simplicity and easy access, consumption smoothing, bailout debt, savings program and income increase, followed by funding independent, total deposits, mindset change, and micro financing. HFI of BMT could be developed gradually. At the first stage, BMT should have the minimum 16 elements of HFI comprising 4 (four) Social Inclusion elements, 4 (four) Financial Inclusion elements, 4 (four) Double bottom-Line elements and 4 (four) Welfare Impact elements. At the second stage, BMT should add the next 16 elements comprising 5 (five) Social Inclusion elements and 3 (three) Financial Inclusion elements, 5 (five) Double Bottom-Line elements and 3 (three) Welfare Impact elements. Moreover, at the third stage, the remaining 24 elements of HFI should be fulfilled. All Islamic financial institution must have the characteristic of HFI.
\end{abstract}

Keywords: Social Inclusion, Financial Inclusion, Holistic Financial Inclusion, BMT

Abstrak. Paper ini bertujuan untuk mendesain roadmap Holistic Financial Inclusion (HFI) oleh Baitul Maal wat Tamwil (BMT), dimana Baitul Maal (BM) menjalankan misi inklusi sosial dan Baitut Tamwil (BT) menjalankan misi inklusi keuangan, menggunakan Analytic Network Process (ANP). Hasil menunjukkan bahwa aspek yang paling penting dalam HFI adalah sustanabilitas, program pengembangan, program pembiayaan dan jasa keuangan mikro Islam, sedangkan elemen terpenting dalam HFI adalah pertemuan berkala, tabungan mikro, kesederhanaan dan kemudahan akses, kelancaran konsumsi, penanggulangan hutang, program simpanan dan kenaikan pendapatan, diikuti dengan kemandirian pendanaan, total deposito, perubahan mindset, dan pembiayaan mikro. HFI di BMT dapat dilakukan dalam beberapa tahap. Pada tahap pertama, BMT harus memiliki minimum 16 elemen yang terdiri dari 4 elemen inklusi sosial, 4 elemen double bottom-line dan 4 elemen dampak kesejahteraan. Pada tahap kedua, BMT harus menambahkan 16 elemen selanjutnya yang terdiri dari 5 elemen inklusi sosial, 3 elemen inklusi keuangan, 5 elemen double bottom-line dan 3 elemen dampak kesejahteraan. Sedangkan pada tahap akhir, 24 elemen HFI lainnya harus dipenuhi. Oleh karena itu, seluruh Lembaga Keuangan Mikro Syariah di Indonesia, khususnya BMT sebaiknya memiliki karakteristik Holistic Financial Inclusion (HFI).

Kata kunci: Inklusi Sosial, Inklusi Keuangan, Holistic Financial Inclusion, BMT

\footnotetext{
${ }^{1}$ Islamic Economic and Finance Dept., Bank Indonesia | ascarya@bi.go.id

2 Islamic Economic and Finance Dept., Bank Indonesia | s_rahmawati@bi.go.id

3 Head of Islamics Economics Dept., Ibn Khaldun Univesity, Indonesia | hendri.tanjung@gmail.com
} 


\section{Introduction}

Industrialization, modernization and globalization have not only resulted in positive impact of welfare improvement, but have also resulted in negative impact in widened the gap between the rich and the poor. Improved welfare has not been fairly shared to all people, resulted in poverty, inequality, social exclusion and financial exclusion. To remedy these negative impacts there have been initiatives of microcredit, microfinance and financial inclusion, which later known as financial inclusion through microfinance. Leyshon and Thrift (1995) stated that financial inclusion was started from financial exclusion of disadvantaged and low income groups of the society, especially the poor, to alleviate poverty. Meanwhile, Marshall (2004) proposed financial inclusion to include community development financial institutions, as well as private sector and voluntary sector, which implicitly to include social inclusion in the initiative of financial inclusion. Moreover, Ledgerwood (2009) has been voiced microfinance as a combination of financial intermediation and social intermediation.

During the rapid development of microfinance, it has been transformed (including shift in paradigms, strategies, and development practices) into microfinance industry triggering the emergence of various conventional microfinance institution (CMFI). Microfinance, which initially not-for-profit and socially oriented institution, has been drifting toward for-profit and commercially oriented CMFI sacrificing the original objective of outreach to the poor for the objective of sustainability, so that the ultimate objective to improve the welfare of the poor has also been affected. Frank (2008), Ghosh and Tassel (2008), and Armendariz, et al. (2013), among others, called these phenomena as double bottom-line (outreach to the poor and financial sustainability) and mission drift (moving away from its original objective of poverty alleviation due to formalization, commercialization and financial sustainability), while Zeller and Meyer (2002) called these as the triangle of microfinance (outreach, sustainability and welfare impact) which are 
impossible to be achieved at the same time, or we could call it 'the impossible trinity of microfinance'.

Microfinance, as a tool of poverty alleviation and empowerment of the poor (faqr or faqir, plural of fuqara'), is not really a new concept in Islam, but it is part of Islamic teachings. For example, Islam lays out certain compulsory obligations (such as zakah) and voluntary obligations (such as infaq and waqf) on the individuals having substantial means for the poor members of the community. Wealth in Islam should not circulate among wealthy people only, but it has to be distributed to others, including the orphans, Al Masakin (the needy) and the wayfarer (Al Qur'an Surah Al Hashr [59]:7). Moreover, in the wealth of people, there was the right of the needy (Al Qur'an Surah Adz Dzaariyat [51]:19 and Al Ma'aarij [70]:24-25). Islamic microfinance (IMFI) not only includes financial inclusion to provide various Islamic financial product and services needed by low income and poor groups of the society, but also provides more holistic framework to enhance financial inclusion, eradicate poverty, and a healthy economy by promoting microfinance, MSE financing, and micro insurance (Naceur, 2015), using redistributive instruments from social funds, such as zakah, infaq and waqf, as well as risk sharing instruments from commercial funds, such as microfinance and micro takaful (Mohieldin, 2012; Iqbal and Mirakhor, 2012 and 2013; Iqbal, 2014). Therefore, IMFI includes social inclusion and financial inclusion as an integral concept of Holistic Financial Inclusion (HFI).

This study aims to design the roadmap of Holistic Financial Inclusion (HFI) by well-known IMFI in Indonesia called Baitul Maal wat Tamwil (BMT), where Baitul Maal (BM) carries out social inclusion of social program and development program, while Baitut Tamwil (BT) carries out financial inclusion of financing program and Islamic micro-financial services, for the poor and micro enterprise (ME), to achieve double bottom-line of outreach and sustainability as well as welfare impact (social and economic), using Analytic Network Process (ANP). 


\section{Literature Review}

Holistic Financial Inclusion (HFI) inherent in BMT is a combination of social inclusion carried out by Baitul Maal division and financial inclusion carried out by Baitut Tamwil division. Social inclusion includes social program and development program provided to poor people (mustahiq) utilizing Islamic social tools, such as zakat, infaq and waqf funds. Financial inclusion includes financing program and Islamic microfinance services provided to mustahiq, which has been graduated from development program, utilizing commercial funds. The objectives of HFI combine social objective of poverty outreach and commercial objective of financial sustainability, solving the problem of double bottom-line, mission drift and commercialization. Moreover, HFI should resulted in welfare impacts, including economic impact and social impact (see table 1).

Table 1. Elements of Holistic Financial Inclusion

\begin{tabular}{|c|c|c|c|}
\hline \multicolumn{4}{|c|}{ Objective - Maqasid Shariah } \\
\hline Faith & Life & Lineage & Wealth \\
\hline \multicolumn{2}{|c|}{ Baitul Maal - Social Inclusion } & \multicolumn{2}{|c|}{ Baitut Tamwil - Financial Inclusion } \\
\hline Social Program & Development Program & Financing Program & Islamic MF Services \\
\hline $\begin{array}{l}\text { 1B-Needs Fulfillment } \\
\text { 2Bailout Debt } \\
\text { 3Health Care } \\
\text { 4Social Services } \\
\text { 5Motivational } \\
\text { Support } \\
\text { 6Halaqah } \\
\text { 7Basic Edu. } \\
\text { Scholarship }\end{array}$ & $\begin{array}{l}\text { 1Regular Meeting } \\
\text { 2Savings Program } \\
\text { 3Skills Training } \\
\text { 4Fam.Fin.Mgt. } \\
\text { Training } \\
\text { 5ME.Mgt.Training } \\
\text { 6ME.Mktg.Training } \\
\text { 7Qardh Financing }\end{array}$ & $\begin{array}{l}\text { 1Easy Access } \\
\text { 2Simplicity } \\
\text { 3Affordable } \\
\text { 4Flexible Collateral } \\
\text { 5Pickup Services } \\
\text { 6Risk Mitigation } \\
\text { 7Monitoring }\end{array}$ & $\begin{array}{l}\text { 1Micro Financing } \\
\text { 2Micro Savings } \\
\text { 3Micro Takaful } \\
\text { 4Transfer } \\
\text { 5Micro Pension Fund } \\
\text { 6Emergency } \\
\text { Financing } \\
\text { 7Bill Payments }\end{array}$ \\
\hline \multicolumn{2}{|c|}{ Double Bottom-Line } & \multicolumn{2}{|c|}{ Welfare Impact } \\
\hline Outreach & Sustainability & Economic Impact & Social Impact \\
\hline $\begin{array}{l}\text { 1No. of Members } \\
\text { 2Total Deposits } \\
\text { 3No. of Borrowers } \\
\text { 4Total Financing } \\
\text { 5Average Financing } \\
\text { 6No. of Branches } \\
\text { 7Area Coverage }\end{array}$ & $\begin{array}{l}\text { 1Funding } \\
\text { Independent } \\
\text { 2Profitability } \\
\text { 3Operat. Efficiency } \\
\text { 4Fund Efficiency } \\
\text { 5Staff Productivity } \\
\text { 6Financing } \\
\text { Performance } \\
\text { 7Asset Growth }\end{array}$ & $\begin{array}{l}\text { 1Consumptn. } \\
\text { Smoothing } \\
\text { 2Income Increase } \\
\text { 3Asset Building } \\
\text { 4Poverty Alleviation } \\
\text { 5Entrepreneurship } \\
\text { 6Skill Improvement } \\
\text { 7Employment }\end{array}$ & $\begin{array}{l}\text { 1Mindset Change } \\
\text { 2Empowered } \\
\text { 3Health } \\
\text { Improvement } \\
\text { 4Knowledge } \\
\text { Improve. } \\
\text { 5School Attendance } \\
\text { 6Social Improvement } \\
\text { 7Religious Improve. }\end{array}$ \\
\hline
\end{tabular}


All of these parts of HFI should be under the scope of Maqasid Sharia laid down by Al Ghazali in his book, al-Mustasfa (1937), where he broken down Maqasid Sharia into 5 (five) essential elements namely: 1) safeguarding the faith (hifz ad-Deen); 2) safeguarding the human self or life (hifz an-Nafs); 3) safeguarding the intellect (hifz al-'Aql); 4) safeguarding the posterity or lineage (hifz an-Nasl); and 5) safeguarding the wealth or property (hifz alMaal). All of these elements considered as necessities (Dharuriyyat) to achieve the objective of Sharia (see the detail in Appendix 1).

There has been a transition in empowerment and development program from microcredit to microfinance. In process, MFIs seem to be the important tool to deliver broader access of financial inclusion (DemirgüçKunt, et al., 2008). The emphasis in recent literatures on the subject of financial inclusion from conventional perspective could be found in Demirgüç-Kunt, et al. (2008), Sarma and Pais (2008), Demirgüç-Kunt and Klapper (2013) and Karpowicz (2014).

In practice, most of recent literature on the subject of social inclusion and financial inclusion are generally related to the performance of conventional MFIs. Accordingly, Zeller and Meyer (2002) present the concept of critical triangle of microfinance involves the need of MFIs to manage simultaneously the problems of outreach, financial sustainability, and impact. Based on this, literature has highlighted the close relationship between microfinance and poverty, meaning that access to finance can help to substantially reduce poverty, such as Pitt and Khandker (1998), Littlefield, et al. (2003), Khandker (2005), and Hermes and Lensink (2011).

In Islam, a holistic financial inclusion is proposed as an integration of social inclusion and financial inclusion and therefore integrate the function of Bait al-Maal and Bait at-Tamwil (Obaidullah, 2008; Ascarya and Cahyono, 2011; and Ali, 2014). The literature shows the implicit explanation of holistic financial inclusion which preceded by social inclusion through empowerment from the institutions of zakah and various charitable activities (Kahf, 2002; Ahmed, 2004a). Meanwhile, there is also the literature that implicitly 
discusses holistic financial inclusion started from Islamic microfinance and financial inclusion, then linked it with the discussion of financing the excluded poor through alms-based sources (Ahmed, 2002; Ahmed, 2004b; Obaidullah, 2008a; Ali, 2014b).

Conceptually, the existing literature on holistic financial inclusion, can be seen in Mohieldin, et al. (2012), Iqbal and Mirakhor (2013), Iqbal (2014), and Ali (2014). Mohieldin, et al. (2012) examine a potential of Islamic finance to improve financial inclusion. To do this, they propose two main elements of Islamic instruments. First, promoting risk-sharing contracts reflected as Islamic microfinance services, such as micro financing, micro takaful, and micro savings. Second, redistributive instruments such as zakah, sadaqah, waqf, and qard hasan offer comprehensive approach to eradicating poverty.

There are literatures which point out the key issues of a trade-off between outreach and sustainability in Islamic MFIs, such as Ahmed (2013), Farooq and Khan (2014), Widiarto and Emrouznejad (2015), and Tamanni and Liu (2015). They proofed that the charitable nature of zakah and waqf can be integrated into micro financing and Islamic inclusive finance to resolve the problem of the trade-off between outreach and sustainability.

\section{Method}

The data needed by Analytic Network Process (ANP) analysis is the primary data obtained from survey, where the samples are selected from the most knowledgeable respondents, in the field of social inclusion and financial inclusion from Islamic perspective, as required by ANP method.

For this study we select 9 (nine) BMT practitioners, which are chosen to fill out simplified pair-wise questionnaires to maintain their consistency. Minimum number of respondent is not required by ANP, since the purpose of the survey is to acquire knowledge from the experts (Eriyatno, 1998). Number of respondents required, ideally, is similar to number of respondents in a focus group discussion (FGD), which is between 6 to 12 respondents for normal FGD, or 3 to 5 respondents for small FGD. 
Thomas L. Saaty, the inventor, describes the Analytic Network Process (ANP) as a multi criteria theory of measurement used to derive relative priority scales of absolute numbers from individual judgments (or from actual measurements normalized to a relative from) that also belong to a fundamental scale of absolute numbers. The ANP provides a general framework to deal with decisions without making assumptions about the independence of higher-level elements from lower level elements and about the independence of the elements within a level as in a hierarchy. In fact the ANP uses network without the need to specify levels (Saaty, 2005).

In more detail, the steps of this research can be seen in figure 1, which comprise of three phases: 1) Model Construction; 2) Model Quantification; and 3) Results Analysis.

\begin{tabular}{|c|c|c|c|}
\hline \multirow{4}{*}{$\begin{array}{c}\text { PHASE 1 } \\
\text { Model } \\
\text { Construction }\end{array}$} & & 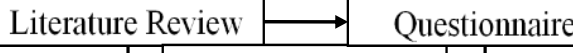 & \\
\hline & & $\longrightarrow$ Indepth Interview & \\
\hline & & ANP Model Construction & \\
\hline & & $\begin{array}{l}\text { ANP Model Validation } \\
-1\end{array}$ & \\
\hline \multirow{4}{*}{$\begin{array}{c}\text { PHASE 2 } \\
\text { Model } \\
\text { Quantification }\end{array}$} & & Pair-wise Questionnaire Design & \\
\hline & RESEARCHER & Pair-wise Questionnaire Testing & EXPERTS \\
\hline & & Pair-wise Survey & \\
\hline & & Data Synthesis \& Analysis & \\
\hline \multirow{2}{*}{$\begin{array}{c}\text { PHASE } 3 \\
\text { Results Analysis }\end{array}$} & & Results Validation & \\
\hline & & Results Interpretation & \\
\hline
\end{tabular}

Figure 1. Steps of ANP Research

Source: Ascarya (2014)

In this empirical study, steps to be done follow three phases suggested by Ascarya (2014) which shows the extension of the three main steps of ANP modeling by Saaty and Vargas (2006), namely model construction, model quantification and results analysis. Phase 1 is model construction or decomposition to identify, analyze and structure the complexity of the problems into an appropriate ANP network, which includes: a) Literature reviews, questionnaires and in-depth interviews with experts and practitioners to comprehend the problem fully; b) Construction of ANP network; and c) Validation of ANP network. Phase 2 is model quantification 
or pair-wise comparison, includes: a) Design pair-wise questionnaires in accordance with ANP network; b) Test the pair-wise questionnaires to experts respondents; c) Survey to selected experts respondents to fill out pair-wise questionnaires; and d) Data processing and synthesis using ANP software SUPERDECISIONS. Phase 3 is results analysis, which includes: a) Calculate rater agreement; b) Validation of the results; and c) Interpretations of the results.

Based on the HFI concept in table 1, the ANP network resulted from step-1, model construction, could be built, which would look like figure 2 .

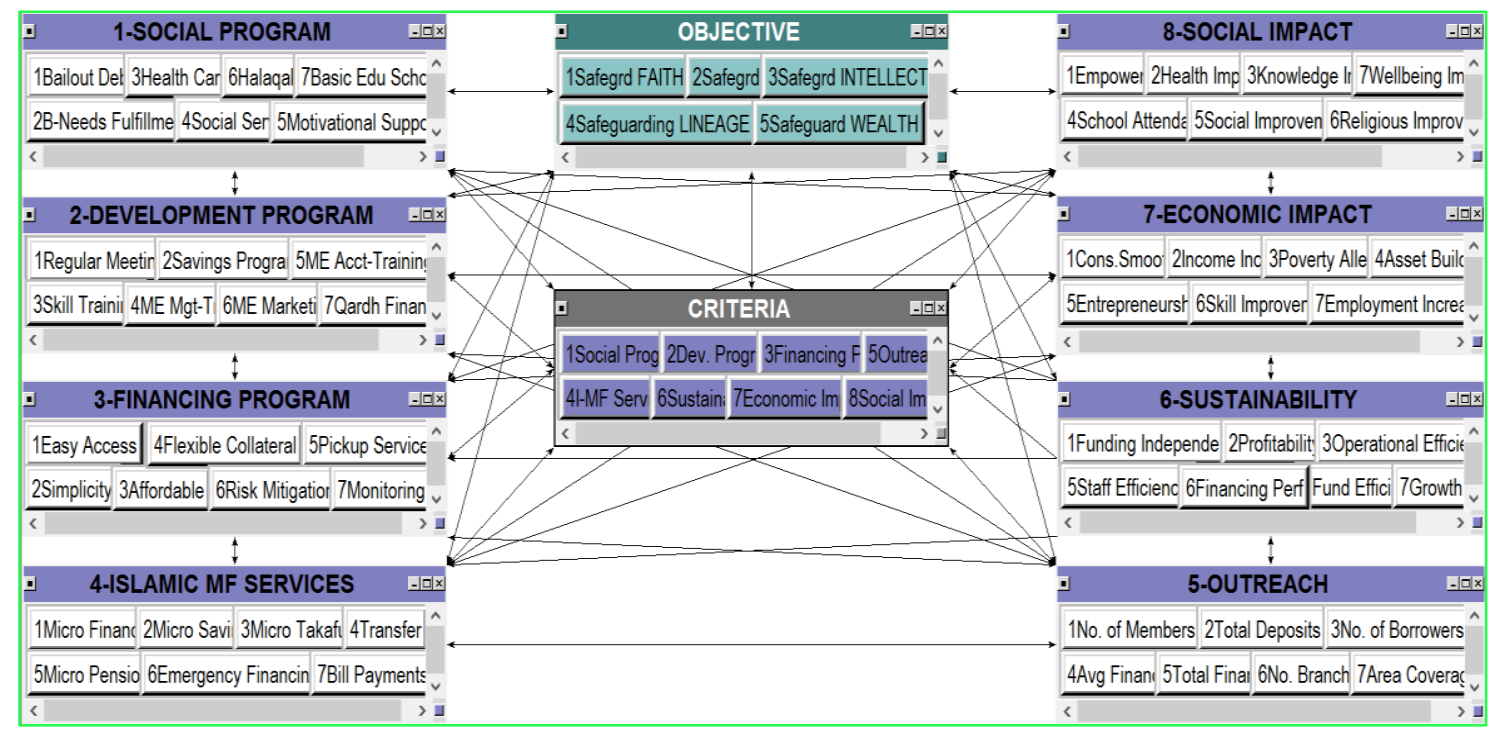

Figure 2. ANP Network

There are 8 (eight) clusters for each aspect of social inclusion (1-social program and 2-development program), financial inclusion (3-financing program and 4-Islamic microfinance services), objectives (5-outreach and 6sustainability) and impact (7-economic impact and 8-social impact), one cluster for Maqasid Sharia and one cluster for criteria comprising all eight aspects as its elements.

All Clusters and their elements are interconnected and interdependent among them, so that it forms circular causation which bears a resemblance to IIE (interactive, integrative and evolutionary)-process-oriented circular causation and continuity model proposed by Choudhury and Hoque (2004). 


\section{Results and Analysis}

\section{ANP Results}

The general ANP results show that the most important Maqasid Shariah are Safeguarding the Wealth (24.6\%), Safeguarding the Faith (21.9\%), Safeguarding the Life (19.4\%), Safeguarding the Intellect (18.5\%) and Safeguarding the Lineage $(15.6 \%)$. Rater agreement $(W=0.454)$ shows high concordance among practitioners. Meanwhile, the most important aspects of HFI are Sustainability (16.4\%), Development Program (14.0\%), Financing Program (13.4\%) and Islamic Microfinance Services (12.6\%), followed by Economic Impact (11.8\%), Social Program (11.1\%), Social Impact (10.6\%) and Outreach (10.0\%). Sustainability is considered as the most important aspect by BMT, while Outreach is the least important aspect, although both of these aspects are part of Double Bottom-Line. Nevertheless, it is a rational and pragmatic decision agreed by practitioners, since BMT could not achieve outreach without being sustainable first. This is also reflected in high rater agreement $(\mathrm{W}=0.358)$.

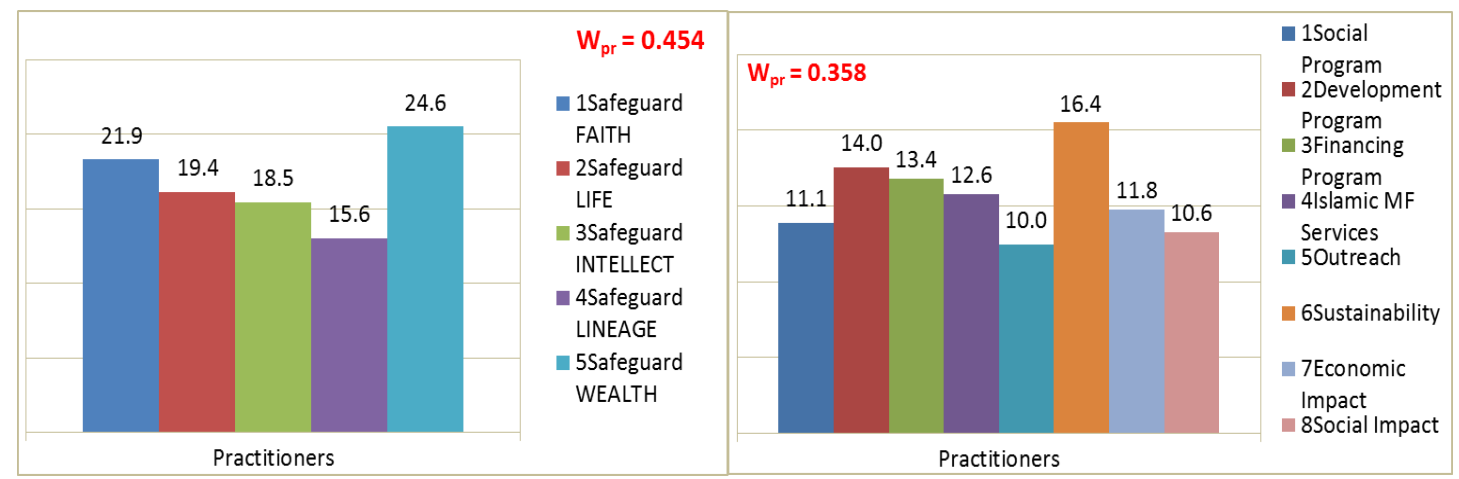

Figure 3. ANP Results of Maqasid Sharia and HFI Aspects

The detailed ANP results show that the most important elements of HFI are regular meeting (Development Program), micro savings (Islamic Microfinance Services), simplicity and easy access (Financing Program), consumption smoothing (Economic Impact), bailout debt (Social Program), savings program (Development Program) and income increase (Economic Impact), followed by funding independent (Sustainability), total deposits (Outreach), mindset change (Social Impact), and micro financing (Financing 
Program). BMT starts with regular meeting of Development Program to build relationship, offers micro savings of Islamic Microfinance Services to improve the mentality of the members and collect funding, and then offers simplicity and easy access of Financing Program for their micro businesses. All 8 (eight) aspects have high rater agreement, especially Financing Program ( $W=0.493)$ and Economic Impact $(\mathrm{W}=0.429)$.

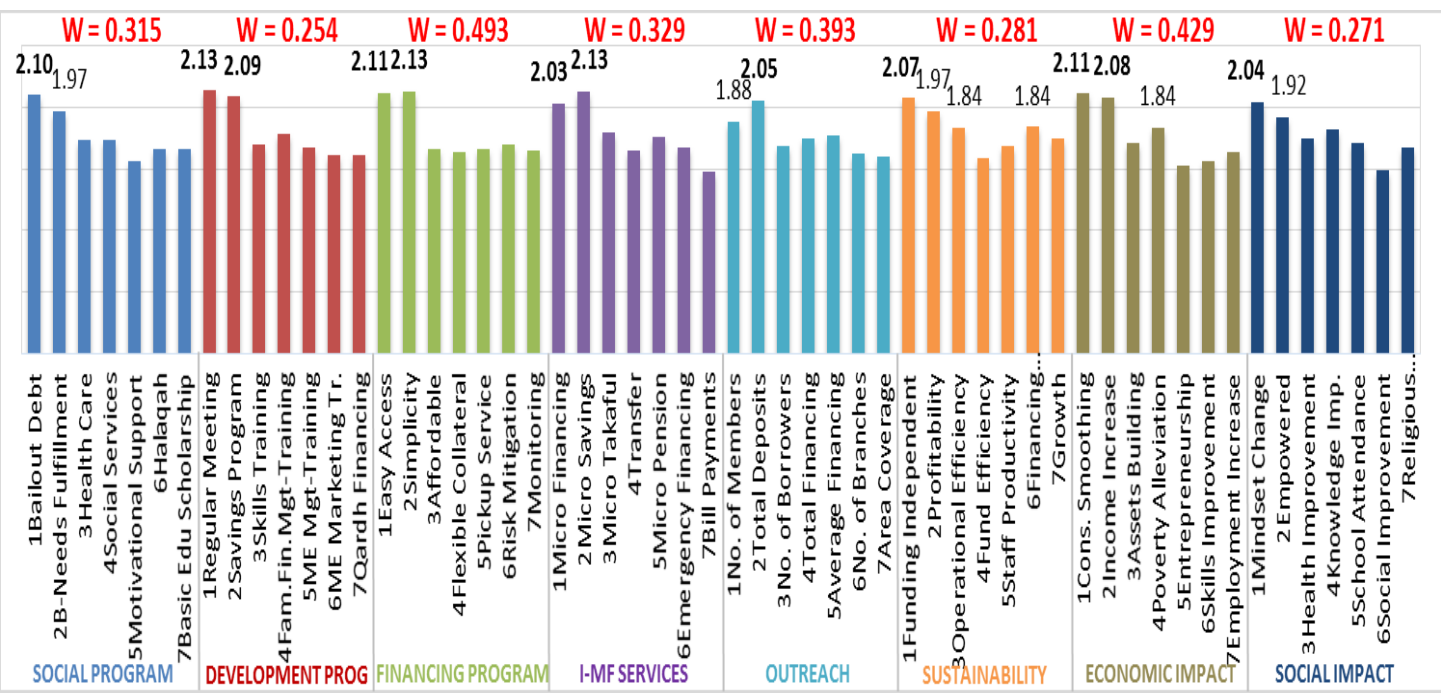

Figure 4. ANP Results of HFI Elements

Holistic Financial Inclusion of BMT could be developed gradually in stages. At the first stage, BMT must focus on the minimum services to be provided by Baitul Maal and Baitut Tamwil as mentioned above (the first two rows of table 2).

Table 2. Development Stages of HFI by BMT

\begin{tabular}{|c|c|c|c|c|c|c|c|}
\hline \multirow{2}{*}{$\begin{array}{c}\text { SOCIAL } \\
\text { PROGAM }\end{array}$} & \multicolumn{3}{|c|}{ BAITUL MAAL } & \multicolumn{4}{|c|}{ BAITUT TAMWIL } \\
\hline & \multicolumn{3}{|c|}{ DEVELOPMENT PROGRAM } & \multicolumn{2}{|l|}{$\begin{array}{c}\text { FINANCING } \\
\text { PROGRAM }\end{array}$} & \multicolumn{2}{|c|}{ SLAMIC-MF SERVICES } \\
\hline 1Bailout Debt & 2.10 & 1Regular Meeting & 2.13 & 2Simplicity & 2.13 & 2Micro Savings & 2.13 \\
\hline $\begin{array}{l}\text { 2B-Needs } \\
\text { Fulfillment }\end{array}$ & 1.97 & $\begin{array}{l}\text { 2Savings } \\
\text { Program }\end{array}$ & 2.09 & 1Easy Access & 2.11 & $\begin{array}{l}\text { 1Micro } \\
\text { Financing }\end{array}$ & 2.03 \\
\hline 3Health Care & 1.73 & $\begin{array}{l}\text { 4Fam.Fin.Mgt- } \\
\text { Training }\end{array}$ & 1.78 & $\begin{array}{l}\text { 6Risk } \\
\text { Mitigation }\end{array}$ & 1.70 & 3Micro Takaful & 1.80 \\
\hline 4Social Services & 1.73 & 3Skills Training & 1.70 & $\begin{array}{l}\text { 5Pickup } \\
\text { Service }\end{array}$ & 1.66 & $\begin{array}{l}\text { 5Micro } \\
\text { Pension }\end{array}$ & 1.76 \\
\hline $\begin{array}{l}\text { 7Basic Edu } \\
\text { Scholarship }\end{array}$ & 1.66 & $\begin{array}{l}\text { 5ME Mgt- } \\
\text { Training }\end{array}$ & 1.68 & 3Affordable & 1.66 & $\begin{array}{l}\text { 6Emergency } \\
\text { Financing }\end{array}$ & 1.67 \\
\hline 6Halaqah & 1.65 & 7Qardh Financing & 1.61 & 7Monitoring & 1.65 & 4Transfer & 1.64 \\
\hline $\begin{array}{l}\text { 5Motivational } \\
\text { Support }\end{array}$ & 1.57 & $\begin{array}{l}\text { 6ME Marketing } \\
\text { Tr. }\end{array}$ & 1.61 & $\begin{array}{l}\text { 4Flexible } \\
\text { Collateral }\end{array}$ & 1.64 & 7Bill Payments & 1.47 \\
\hline
\end{tabular}


Meanwhile, the objectives to be achieved and the impacts to be expected at the first stage must focus on the minimum social objectives, commercial objectives and welfare impacts that should be accomplished, as can be seen in the first two rows of table 3 .

Table 3. Development Stages of HFI by BMT

\begin{tabular}{|c|c|c|c|c|c|c|c|}
\hline \multicolumn{3}{|c|}{ DOUBLE BOTTOM-LINE } & \multicolumn{5}{|c|}{ WELFARE IMPACT } \\
\hline \multicolumn{2}{|c|}{ OUTREACH } & \multirow{2}{*}{$\begin{array}{l}\text { SUSTAINABILITY } \\
\text { 1Funding } \\
\text { Independent }\end{array}$} & \multicolumn{3}{|c|}{ ECONOMIC IMPACT } & \multicolumn{2}{|c|}{ SOCIAL IMPACT } \\
\hline $\begin{array}{l}\text { 2Total } \\
\text { Deposits }\end{array}$ & 2.05 & & 2.07 & 1Cons. Smoothing & 2.11 & $\begin{array}{l}\text { 1Mindset } \\
\text { Change }\end{array}$ & 2.04 \\
\hline $\begin{array}{l}\text { 1No. of } \\
\text { Members }\end{array}$ & 1.88 & 2Profitability & 1.97 & 2Income Increase & 2.08 & 2Empowered & 1.92 \\
\hline $\begin{array}{l}\text { 5Average } \\
\text { Financing }\end{array}$ & 1.77 & $\begin{array}{l}\text { 6Financing } \\
\text { Performance }\end{array}$ & 1.84 & $\begin{array}{l}\text { 4Poverty } \\
\text { Alleviation }\end{array}$ & 1.84 & $\begin{array}{l}\text { 4Knowledge } \\
\text { Imp. }\end{array}$ & 1.82 \\
\hline $\begin{array}{l}\text { 4Total } \\
\text { Financing }\end{array}$ & 1.75 & $\begin{array}{l}\text { 3Operational } \\
\text { Efficiency }\end{array}$ & 1.84 & 3Assets Building & 1.70 & $\begin{array}{l}\text { 3Health } \\
\text { Improvement }\end{array}$ & 1.75 \\
\hline $\begin{array}{l}\text { 3No. of } \\
\text { Borrowers }\end{array}$ & 1.69 & 7Growth & 1.74 & $\begin{array}{l}\text { 7Employment } \\
\text { Increase }\end{array}$ & 1.64 & $\begin{array}{l}\text { 5School } \\
\text { Attendance }\end{array}$ & 1.71 \\
\hline $\begin{array}{l}\text { 6No. of } \\
\text { Branches }\end{array}$ & 1.62 & 5Staff Productivity & 1.68 & $\begin{array}{l}\text { 6Skills } \\
\text { Improvement }\end{array}$ & 1.57 & $\begin{array}{l}\text { 7Religious } \\
\text { Improvement }\end{array}$ & 1.67 \\
\hline $\begin{array}{l}\text { 7Area } \\
\text { Coverage }\end{array}$ & 1.60 & 4Fund Efficiency & 1.58 & 5Entrepreneurship & 1.52 & $\begin{array}{l}\text { 6Social } \\
\text { Improvement }\end{array}$ & 1.48 \\
\hline
\end{tabular}

\section{Roadmap of HFI Development}

At the first stage, BMT should have the minimum elements of HFI, which include: bailout debt and basic needs fulfillment (Social Program), regular meeting and savings program (Development Program), simplicity and easy access (Financing Program), micro savings and micro financing (Islamic Microfinance Services), total deposits and number of members (Outreach), funding independent and profitability (Sustainability), consumption smoothing and income increase (Economic Impact), as well as mindset change and empowered (Social Impact).

At the second stage, BMT could choose its own roadmap of HFI development. BMT could give more attention to develop Social Inclusion by Baitul Maal or Financial Inclusion by Baitut Tamwil. For example (see table 2), BMT could develop BT by improving its financing program with better risk mitigation and pick-up services, as well as by providing Micro Takaful and Micro Pension (moving from [2, 2] vertically to [2, 4]), etc. Meanwhile, BMT could focus on achieving Objective (see table 3), by improving Financing 
Performance and Operational Efficiency (Financial Sustainability), as well as Average Financing and Total Financing (Outreach), which means moving
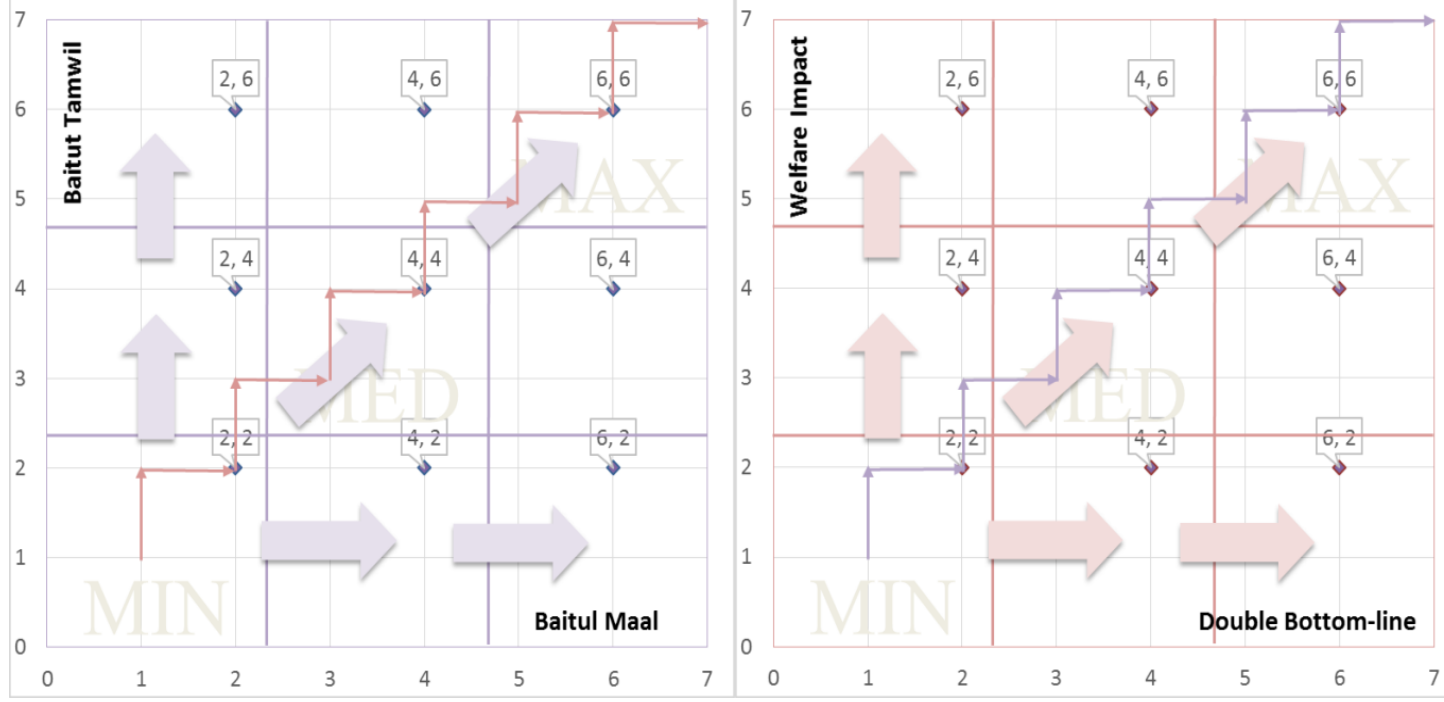

from [2, 2] horizontally to [4, 2]. Other elements of each eight HFI aspects, which are not in the top priority, do not mean that they are not important. They are all important and necessary, but they could be added gradually in due time.

Figure 5. Alternative Roadmap of HFI Development

Based on all 9 respondent of practitioners, the roadmap of HFI of BMT development can be seen in figure 10. Figure 10 left shows a little skewed development of Baitul Maal and Baitut Tamwil elements towards Baitul Maal from the minimum point $[2,2]$, point $[3,3]$, and to point $[4.5,3.5]$, which means the second stage development of Baitul Maal and Baitut Tamwil from $8^{\text {th }}$ to $16^{\text {th }}$ most important elements should have 9 elements of Baitul Maal (i.e., social inclusion) and 7 elements of Baitut Tamwil (i.e., financial inclusion). Therefore at the second stage, the added elements of HFI include healthcare and social services (Social Program), Family Financial Management Training, Skills Training and ME Management Training (Development program), risk mitigation (Financing Program), as well as micro takaful and micro pension (Islamic Microfinance Services). 
Then in the next stage it moves to point $[5,5]$, point $[5.5,6.5]$, which means more Baitut Tamwil elements development, and finally it moves to final stage of $[7,7]$, where additional Baitul Maal such as Motivational Support (Social Program) and ME Marketing Training (Development Program) are optional programs. The priority to develop balanced Baitul Maal and Baitut Tamwil is agreed by most large BMT. Small BMT usually is still struggling for its sustainability, so that developing Baitul Maal is not in its top priority.

Meanwhile, figure 10 right shows a skewed Double Bottom-Line and Welfare Impact priority towards Double Bottom-Line from the minimum point $[2,2]$, point $[3,3]$, point $[4.5,3.5]$ and to point $[5.5,4.5]$, then it moves to point $[7,5.5]$, which means more priority on Double Bottom-Line elements, and finally it moves to final stage of $[7,7]$. This shows that achieving sustainability of BMT and outreach to the poor should be prioritized than achieving economic and social impacts.

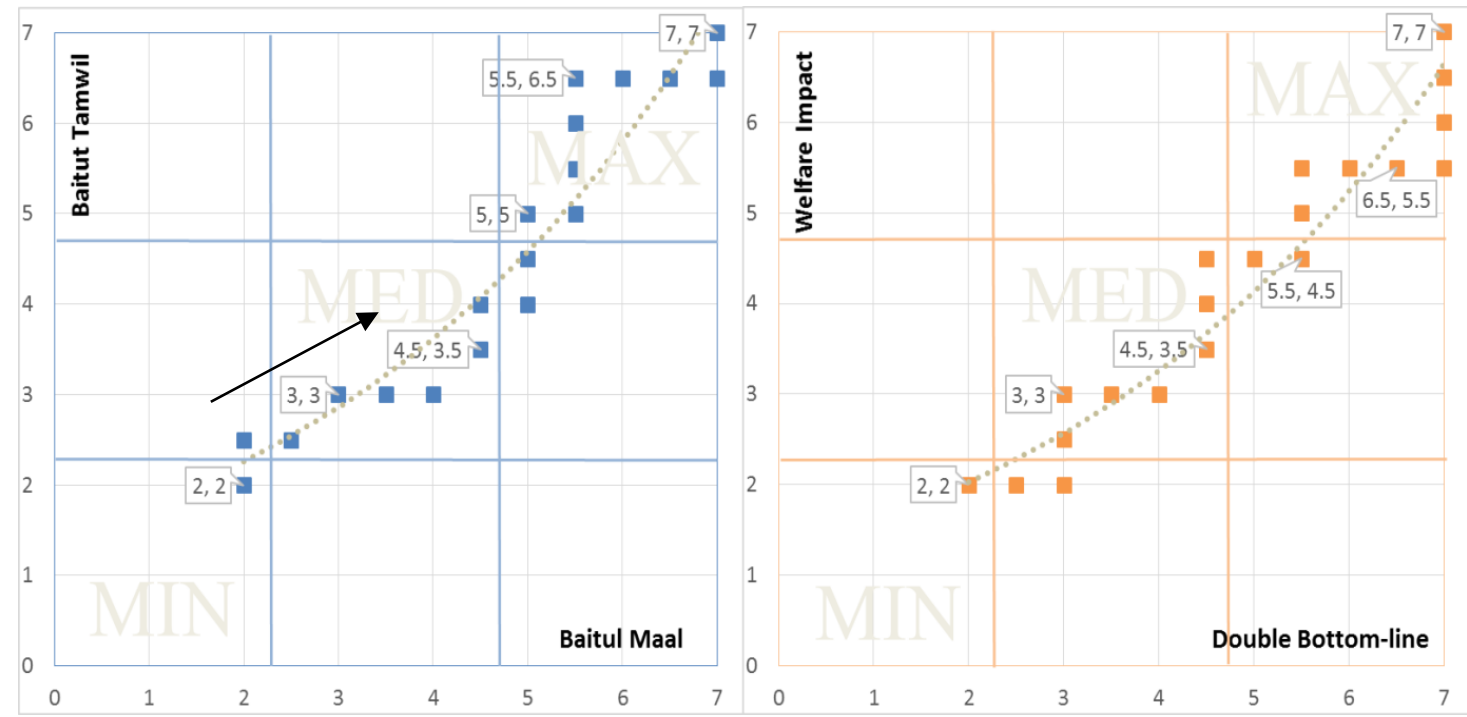

Figure 6. Roadmap of HFI Development of BMT

The roadmap of social inclusion for Baitul Maal of BMT can be seen in figure 11 (left), where it suggests balanced development between Social Program and Development Program. At the second stage, the added elements, consecutively, are Family Financial Management Training 
(Development Program), Health Care and Social Services (Social Program) and Skills Training (Development Program). At the third stage, the added elements, consecutively, are ME Management Training (Development Program), Basic Education Scholarship and Halaqah (Social Program), ME Marketing Training and Qardh Financing (Development Program) and finally Motivational Support (Social Program). This shows that Baitul Maal should have balanced social services and activities in serving the community, especially the poor and the needy.

Meanwhile, the roadmap of financial inclusion for Baitut Tamwil of BMT can be seen in figure 11 (right), where it suggests to develop Islamic Microfinance Services first at the second stage and balanced development at the third stage. At the second stage, the added elements, consecutively, are Micro Takaful and Micro Pension (Islamic Microfinance Services), Risk Mitigation (Financing Program). At the third stage, the added elements, consecutively, are Emergency Financing (Islamic Microfinance Services), Pickup Services, Affordable and Monitoring (Financing Program), Transfer (Islamic Microfinance Services), Flexible Collateral (Financing Program), and finally Bill Payments (Islamic Microfinance Services). This suggests that Baitut Tamwil should not only provide financing, but should also provide a variety of Islamic microfinance services needed by members.

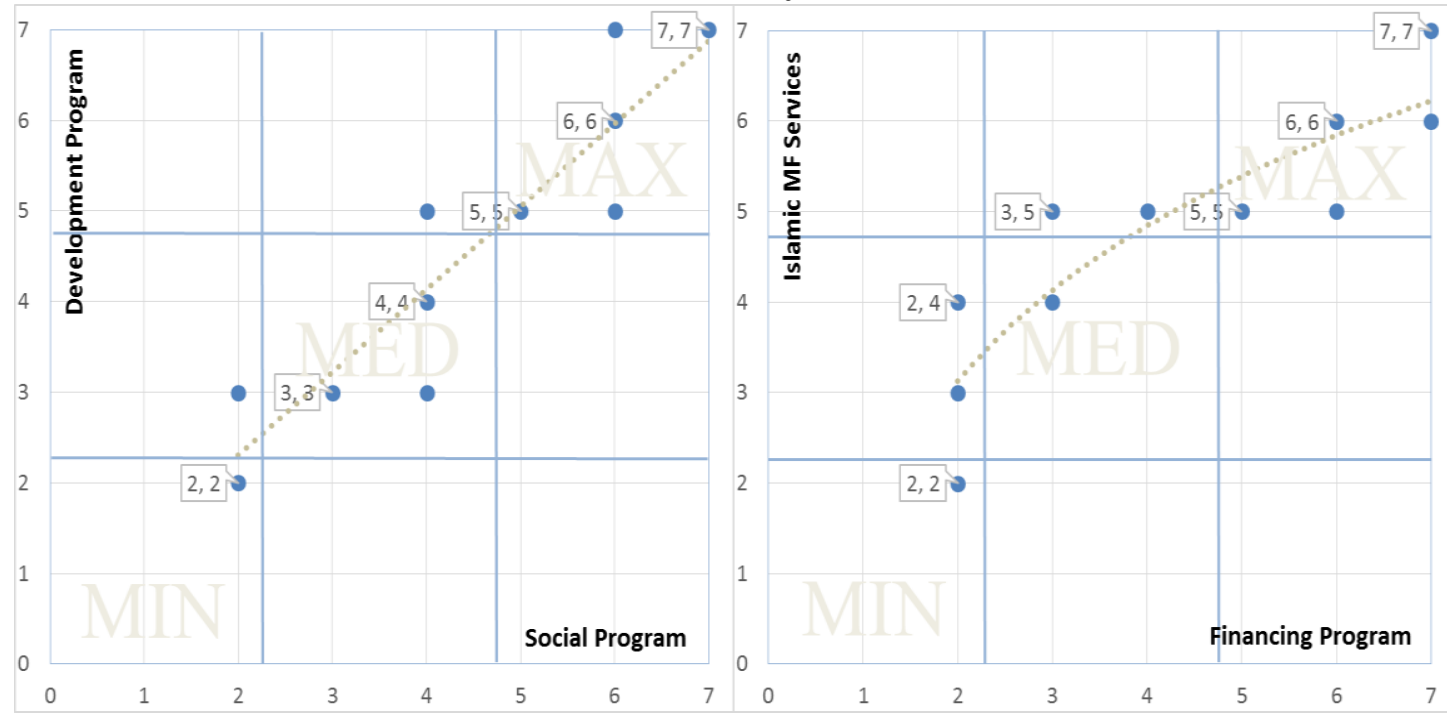

Figure 7. Roadmap of Social Inclusion for BM and Financial Inclusions for BT 
The roadmap of Double Bottom-Line achievement can be seen in figure 12 (left), where it gives priority to achieve Sustainability in the second stage and Outreach in the third stage. At the second stage, the added elements, consecutively, are Financing Performance and Operational Efficiency (Sustainability), Average Financing and Total Financing (Outreach). At the third stage, the added elements, consecutively, are Growth (Sustainability), Number of Borrower (Outreach), Staff Productivity (Sustainability), Number of Branches and Area Coverage (Outreach), and finally Fund Efficiency (Sustainability). It seems that BMT practitioners take realistic choice to focus on sustainability first, since it is considered as prerequisite to achieve outreach.

Meanwhile, the roadmap of Welfare Impact can be seen in figure 12 (right), where Social Impact should be given priority. At the second stage, the added elements, consecutively, are Poverty Alleviation (Economic Impact), Knowledge Improvement, Health Improvement and School Attendance (Social Impact), Asset Building (Economic Impact), Religious Improvement (Social Impact), Employment Increase, Skills Improvement and Entrepreneurship (Economic Impact), and finally Social Improvement (Social Impact). After economic impact has been achieved just above the minimum, BMT focuses on achieving social impact.

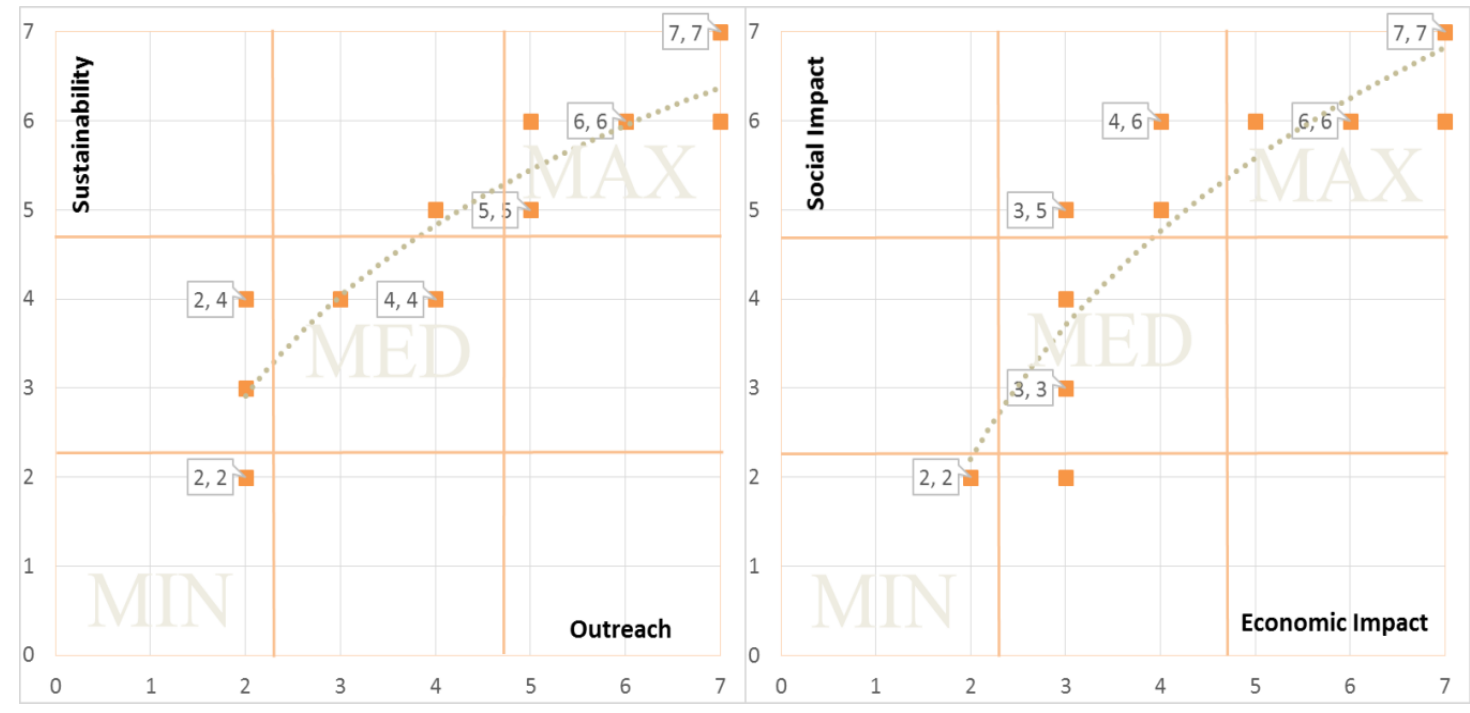

Figure 8. Roadmap of Double Bottom-Line and Welfare Impact for BMT 


\section{Conclusion}

Baitul Maal wat Tamwil or BMT is an Indonesian genuine Islamic microfinance institution (IMFI) in the form of Islamic Cooperatives featuring inherent holistic financial inclusion (HFI), where it combines social finance to achieve social inclusion by Baitul Maal division and commercial finance to achieve financial inclusion by Baitut Tamwil division. Social inclusion includes social program and development program provided to poor people (mustahiq) utilizing Islamic social tools, such as zakat, infaq and waqf funds. Financial inclusion includes financing program and Islamic microfinance services provided to graduated mustahiq utilizing commercial funds, MSEs and other BMT members. There is no dichotomy between real and financial sectors, as well as between for-profit and not-for profit activities or institutions.

The general ANP results show that the most important aspects of HFI are Sustainability, Development Program, Financing Program and Islamic Microfinance Services, followed by Economic Impact, Social Program, Social Impact and Outreach. Sustainability is the most important and Outreach is the least important, while both are part of Double Bottom-Line, which is rational and pragmatic decision, since BMT could not achieve outreach without being sustainable first.

The detailed ANP results show that the most important elements of HFI are regular meeting (Development Program), micro savings (Islamic Microfinance Services), simplicity and easy access (Financing Program), consumption smoothing (Economic Impact), bailout debt (Social Program), savings program (Development Program) and income increase (Economic Impact), followed by funding independent (Sustainability), total deposits (Outreach), mindset change (Social Impact), and micro financing (Financing Program).

Holistic Financial Inclusion of BMT could be developed gradually in stages. At the first stage, BMT should have the minimum 16 elements of HFI comprising 4 (four) Social Inclusion elements, 4 (four) Financial Inclusion 
elements, 4 (four) Double bottom-Line elements and 4 (four) Welfare Impact elements, which include: bailout debt and basic needs fulfillment (Social Program), regular meeting and savings program (Development Program), simplicity and easy access (Financing Program), micro savings and micro financing (Islamic Microfinance Services), total deposits and number of members (Outreach), funding independent and profitability (Sustainability), consumption smoothing and income increase (Economic Impact), as well as mindset change and empowered (Social Impact).

At the second stage of development, BMT should add the next 16 elements comprising 5 (five) Social Inclusion elements and 3 (three) Financial Inclusion elements, 5 (five) Double Bottom-Line elements and 3 (three) Welfare Impact elements, which include: healthcare and social services (Social Program), Family Financial Training, Skills Training and ME Management Training (Development program), risk mitigation (Financing Program), as well as micro takaful and micro pension (Islamic Microfinance Services), average financing and total financing (Outreach), financing performance, operational efficiency and growth (Sustainability), poverty alleviation (Economic Impact), as well as knowledge improvement and health improvement (Social Impact).Moreover, at the third stage, the remaining 24 elements of HFI should be fulfilled.

There is no dichotomy in Islamic perspective between social not-forprofit activities and commercial for-profit activities. However, this dichotomy exists in conventional world, so that BMT should have at least three permits for its activities as IMFI, as zakah, infaq and sadaqah institution and as waqf institution. BMT should have its own regulation to be able to operate as it should be to carry out the duty of holistic financial inclusion effectively.

Affected by current secular setting and struggle for sustainability, small BMT could not yet fully function as HFI and would focus more on commercial for-profit activities. Moreover, most BM division assets is just 1\% of BT division assets, since most BMTs have not been licensed to be waqf manager. Therefore, BMT should be encouraged to become waqf manager, so 
that BM division assets would increase significantly and consequently could be better achieved the duty of HFI.

The concept of holistic financial inclusion or HFI is a new concept that should be more frequently voiced and applied to replace the more secular and partial concept of financial inclusion, especially in the field Islamic economics and finance. All Islamic financial institutions, especially Islamic Cooperatives as IMFI, should have the characteristic of HFI.

\section{References}

Adnan, M., and Ajija, S. (2015). The Effectiveness of Baitul Maal wat Tamwil in Reducing Poverty. Humanomics, Vol. 31(2): 160-182.

Ahmed, H. (2002). Financing Microenterprises, An Analytical Study of Islamic Microfinance Institutions. Islamic Economic Studies, Vol. 31(2): 160-182.

Ahmed, H. (2013). Financial Inclusion and Islamic Finance, Organizational Formats, Products, Outreach and Sustainability. In Z. Iqbal, and A. Mirakhor (Eds.), Economic Development and Islamic Finance. Washington DC: World Bank Publication.

Alaeddin, O., and Anwar, N. (2012, November).Critical Analysis of Diverse Funding of Islamic Microfinance Institution, A Case Study in BMT Amanah Ummah Surabaya Indonesia. Paper presented at the 2nd ISRA Colloquium, Kuala Lumpur.

Alam, M., and Getubig, M. (2010). Guidelines for Establishing and Operating Grameen-Style Microcredit Programs, Based on the Practices of Grameen Bank and the Experiences of Gramees Trust and Grameen Foundation Partners. USA: Grameen Foundation.

Ali, A. E. E. S. (2014). Islamic Microfinance, Moving Beyond Financial Inclusion (Working Paper 1435-11). IRTI

Ali, M. K. (2014b). Integrating Zakah, Awqaf and Islamic Microfinance for Poverty Alleviation, Three Models of Islamic Micro Finance (Working Paper Series1435-19). IRTI.

Alpay, S. (2011, May). Enhancing employability in OIC Countries, The Role of Capacity Building and Microfinance. Paper presented at the Meeting on Addressing Unemployment in the IDB Member Countries in the PostCrisis World. IDB Group: Jeddah.

An-Nawawi, Y. (2001). Riyadu as-Solihin. Beirut: Muassasah Ar-Risalah.

Armendariz, B., and Morduch, J. (2010). The Economics of Microfinance (2nd Ed.). London: The MIT Press. 
Armendariz, B., D'Espallier, B., Hudon, M., andSzafarz, A. (2013). Subsidy Uncertainty and Microfinance Mission Drift (CEB Working Paper11).

Ascarya. (2014). Sustainable Conventional and Islamic Microfinance Models for Micro Enterprises. ISRA International Journal of Islamic Finance, Vol. 6(2): 49-85.

Ascarya, and Cahyono, W. (2011). Comparing the Sustainability of Conventional and Islamic Microfinance and Models in Indonesia", paper presented at the Political Economy of Trade Liberalization in Developing East Asia, Sustainability, Governance, and the Role of Small Business. Malang: University of Brawijaya.

Atnafu, H. (2010). How Efficiently are the Ethiopian MFIs Extending Financial Services to the Poor? A Comparison with the Commercial Banks (Master Thesis). Addis Ababa University.

Bank Indonesia. (2012). Kodifikasi Peraturan Bank Indonesia Kelembagaan Penilaian Tingkat Kesehatan Bank. Jakarta: Bank Indonesia.

Bank Indonesia. (2014). Booklet Financial Inclusion. Jakarta: Bank Indonesia.

Beck, T., and Hesse, H. (2006). Bank efficiency, Ownership and Market Structure Why Are Interest Spreads So High in Uganda? (Discussion Paper Series 277). Department of Economics, University of Oxford.

Beik, I. S., and Arsyanti, L. D. (2015). Construction of CIBEST Model as Measurement of Poverty and Welfare Indices from Islamic Perspective. Journal Al-Iqtishad, Vol. 7(1): 88-104.

Bhatt, N., and Tang, S. (2001). Delivering Microfinance in Developing Countries, Controversies and Policy Perspectives. Policy Studies Journal, Vol. 29(2): 319-333.

Bogan, V., Johnson, W., and Mhlanga, N. (2007). Does Capital Structure Affect the Financial Sustainability of Microfinance Institutions? (Working paper). Department of Applied Economics and Management, Cornell University.

Bremer, J. (2014, May). Zakat and Economic Justice, Emerging International Models and Their Relevance for Economic Growth. Paper presented at World Zakat Forum, WZF: New York.

Campion, A. (2000). Improving Internal Control, A Practical Guide for Microfinance Institutions. Washington DC: ACCION.

Centre for the Study of Financial Innovation (CSFI). (2014). Microfinance Banana Skins 2014. London: CSFI.

Charitonenko, S., and Afwan, I. (2003).Commercialization of Microfinance, Indonesia. Manila: Asian Development Bank.

Cokro, W. M., and Ismail, A. G. (2008). Sustainability of BMT Financing for Developing Micro-enteprises. MPRA Paper, 7434. 
Consultative Group to Assist the Poor (CGAP). (2006). Good Practice Guidelines for Funders of Microfinance (2nd Edition). Washington DC: CGAP.

Consultative Group to Assist the Poor (CGAP). (2003). Definitions of Selected Financial Terms, Ratios, and Adjustments for Microfinance (3rd edition). Washington DC: CGAP.

Cull, R., Demirgüç-Kunt, A., and Morduch, J. (2007). Financial Performance and Outreach, A Global Analysis of Leading Microbanks. The Economic Journal, Vol. 117(517). F107-F133.

Cull, R., Demirgüç-Kunt, A., and Morduch, J. (2008). Microfinance Meets the Market. Policy Research Working Paper, Vol. 4630: 1-38.

Demirgüç-Kunt, A., and Klapper, L. (2013). Measuring Financial Inclusion, Explaining Variation in Use of Financial Services across and within Countries. Brookings Papers on Economic Activity, 279-321.

Demirgüç-Kunt, A., Beck, T., and Honohan, P. (2008). Finance for All, Policies and Pitfalls in Expanding Access. Washington DC: World Bank.

Edgcomb, E. L. (2001). Assessment Tools for Microenterprise Training and Technical Assistance. Washington, DC: The Aspen Institute.

Evans, A. C., and Branch, B. (2002). A Technical Guide to PEARLS, A Performance Monitoring System. Madison: World Council of Credit Unions, Inc.

Farooq, M., and Khan, Z. (2014). The Social and Financial Performance of Conventional and Islamic Microfinance Institutions in Pakistan. AlIdah, Vol. 28: 17-35.

Fehr, D., and Hishigsuren, G. (2004). Raising Capital for Microfinance, Sources of Funding and Opportunities for Equity Financing (CFS Working Paper 200401). Center for Financial Studies-Southern New Hampshire University.

Frank, C., and Lynch, E. (2008). Stemming the Tide of Mission Drift, Microfinance Transformations and the Double Bottom Line. New York: Women's World Banking Focus Note.

Ghosh, S., and Tassel, E. V. (2008). A Model of Mission Drift in Microfinance Institution. Department of Economics, Florida Atlantic University.

Global Islamic Finance Report. (2012). Global Islamic Microfinance Landscape. In H. Dar et al. (Eds.), Global Islamic Finance Report 2012 (London, Edbiz Consulting Limited: 183-204).

Global Partnership for Financial Inclusion (GPFI). (2011). Global StandardSetting Bodies and Financial Inclusion for the Poor, Toward Proportionate Standards and Guidance. GPFI White Paper.

Hadisumarto, W. B. M. C. and Ismail, A. G. B. (2010). Improving the Effectiveness of Islamic Micro-financing. Humanomics, Vol. 26(1): 65-75. 
Hassan, M. K., and Ashraf, A. (2010). An Integrated Poverty Alleviation Model Combining Zakat, Awqaf and Micro-Finance. M. H. A. G. Ismail (Ed.) The Seventh International Conference - The Tawhidi Epistemology, Zakat and Waqf Economy (pp. 261-281). Institut Islam Hadhari, Universiti Kebangsaan Malaysia, Bangi, Malaysia.

Hermes, N., and Lensink, R. (2011). Microfinance, Its Impact, Outreach, and Sustainability. World Development, Vol. 39(6): 875-881.

Hermes, N., Lensink, R., and Meesters, A. (2008). Outreach and Efficiency of Microfinance Institutions. University of Groningen: Faculty of Economics and Business.

Hoque, N., Khan, M. A., and Mohammad, K. D. (2015). Poverty Alleviation by Zakah in a Transitional Economy, A Small Business Entrepreneurial Framework. Journal of Global Entrepreneurship Research, Vol. 5(7): 1-20.

Hoque, N., Mamun, A., and Mamun, A. M. A. (2014). Dynamics and Traits of Entrepreneurship, An Islamic Approach. World Journal of Entrepreneurship, Management and Sustainable Development, Vol. 10(2): 128-142.

International Finance Corporation. (2014), Islamic Banking Opportunities across Small and Medium Enterprises in MENA. Washington DC: International Finance Corporation.

International Fund for Agricultural Development (IFAD). (2006). Assessing and Managing Social Performance in Microfinance. Rome: IFAD.

Iqbal, Z. (2014, June). Enhancing Financial Inclusion through Islamic Finance. Paperpresented at Financial Inclusion Conference, World Bank, Istanbul.

Iqbal, Z., and Mirakhor, A. (2012). Financial Inclusion, Islamic Finance Perspective. Journal of Islamic Business and Management, Vol. 2(1): 35-64.

Iqbal, Z., and Mirakhor, A. (2013). Islam's Perspective on Financial Inclusion. Z. Iqbal, and A. Mirakhor. Economic Development and Islamic Finance, 179200). Washington DC: World Bank Publications.

Islamic Research and Training Institute and Thomson Reuters. (2014). Islamic Social Finance Report 2014. IRTI and Thomson Reuters.

Jariya, A. M. (2013). True Economy Prosperity through Poverty Alleviation Islamic Microfinance as Commercial Venture. International Journal of Business, Economic and Law, Vol. 2(2): 49-53.

Juwaini, A., et al. (2010, May). BMT (Baitul Maal wa Tamwil) Islamic Micro Financial Services for the Poor. Paper presented at the ISO/COPOLCO Workshop, Bali.

Kahf, M. (2002). Role of Zakah and Awqaf in Reducing Poverty, A Proposed Institutional Setting within the Spirit of Shari'ah", Thoughts on Economics, Vol. 18(3): 39-67. 
Kar, A. K. (2010). Sustainability and Mission Drift in Microfinance. Helshinki, Hanken School of Economics.

Khadijah, S. A., et al. (2013). Sustainability of Islamic Micro Finance Institutions (IMFIs). Universal Journal of Accounting and Finance, Vol. 1(2): 70-77.

Khandker, S. R. (2003). Micro-Finance and Poverty, Evidence Using Panel Data from Bangladesh. (Policy Research Working Paper 2945), World Bank.

Ledgerwood, J. (1999). Microfinance Handbook, An Institutional and Financial Perspective. Washington DC: World Bank.

Leyshon, A., and Thrift, N. (1995). Geographies of Financial Exclusion, Financial Abandonment in Britain and the United States. Transactions of the Institute of British Geographers, Vol. 20(3): 312-341.

Littlefield, E., Morduch, J., and Hashemi, S. (2003). Is Microfinance an Effective Strategy to Reach the Millenium Development Goals. Focus Note of CGAP 24.

M Alfriska, M., and Haryani, S. (2011). Regional Development Banks Performance in Indonesia. Proceedings of the First International Credit Union Conference on Social Microfinance and Community Development (pp. 91-94).Jakarta: BKCU Kalimantan and Gunadarma University.

MicroRate. (2014). Technical Guide, Performance and Social Indicators for Microfinance Institutions. Washington DC: MicroRate.

Mohieldin, M., et al. (2012). The Role of Islamic Finance in Enhancing Financial Inclusion in Organization of Islamic Cooperation (OIC) Countries. Islamic Economic Studies, Vol. 20(2): 55-120.

Morduch, J. (2000). The Microfinance Schism. World Development, Vol. 28(4): 617-629.

Naceur, S. B., Barajas, A., and Massara, A. (2015). Can Islamic Banking Increase Financial Inclusion? IMF Working Paper [15/31].

Natilson, N., and Bruett, T. (2001). Financial Performance Monitoring, A Guide for Board Members of Microfinance Institutions. Bethesda: Development Alternatives, Inc.

Nazirwan, M. (2015). The Dynamic Role and Performance of Baitul Maal Wat Tamwil, Islamic Community-Based Microfinance in Central Java (Doctoral Dissertation). Victoria University.

Njuguna, A. G. (2012). Critical Success Factors for a Micro-Pension Plan, an Exploratory Study. International Journal of Financial Research, Vol. 3(4): 8297.

Obaidullah, M. (2008). Introduction to Islamic Finance. New Delhi: IBF Net Limited, India. 
Obaidullah, M. (2008). Role of Microfinance in Poverty Alleviation. Jeddah: IRTIIDB.

Obaidullah, M., and Khan, T. (2008). Islamic Microfinance Development, Challenges and Initiatives. Dialogue Paper Policy Dialogue Paper 2. Saudi Arabia: Islamic Research and Training Institute-Islamic Development Bank.

OECD. (2012). The Role of Empowerment for Poverty Reduction and Growth. Policy Guidance Note. Retrieved November 11, 2015.

Pitt, M. M., and Khandker, S. R. (1998). The Impact of Group-Based Credit Programs on Poor Households in Bangladesh, Does the Gender of Participants Matter?. Journal of Political Economy, Vol. 106(5): 958-996.

Rahman, A. (2013). Financial Inclusion as Tool for Combating Poverty. Bangladesh Bank.

Rahman, R. A., and Dean, F. (2013). Challenges and Solutions in Islamic Microfinance. Humanomics, Vol. 29(4): 293-306.

Reyes, G. P. (2010).Financial Inclusion Indicators for Developing Countries, The Peruvian Case. Peru: Superintendency of Banking.

Rhyne, E. (2009). Microfinance for Bankers and Investors, Understanding the Opportunity at the Bottom of the Pyramid. New York: McGraw-Hill.

Robinson, M. S. (2001). The Microfinance Revolution, Sustainable Finance for the Poor. Washington DC: World Bank.

Rokhman, W. (2013). Baitul Mal Wat Tamwil (BMT) and Poverty Alleviation. Qudus International Journal of Islamic Studies, Vol. 1(2): 181-196.

Rosenberg, R. (2009). Measuring Results of Microfinance Institutions, Minimum Indicators that Donors and Investors Should Track. Washington DC: The World Bank.

Rusydiana, A. S., and Devi, A. (2013). Challenges in Developing Baitul Maal Wat Tamwil (BMT) in Indonesia Using Analytical Network Process (ANP). Business and Management Quarterly Review, Vol. 4(2): 51-62.

Saaty, TL. (2005), Theory and Applications of the Analytic Network Process, Decision Making with Benefits, Opportunities, Costs and Risks. Pittsburgh: RWS Publications.

Saaty, TL and Vargas, LG. (2006). Decision Making with the Analytic Network Process, Economic, Political, Social and Technological Applications with Benefits, Opportunities, Costs and Risks. New York: Springer Science + Business Media.

Saha, S. (2011). Provision of Health Services for Microfinance Clients, Analysis of Evidence from India. International Journal Medical Public Health, Vol. 1(1):1-5. 
Sarma, M., andPais, J. (2008).Financial Inclusion and Development, A Cross Country Analysis. New Delhi: Madras Schools of Economics.

Seibel, H. D. (2005). Islamic Microfinance in Indonesia. Sector Project Financial Systems Development. Eschborn: Deutsche Gesellschaftfür Technische Zusammenarbeit.

Shirazi, N. S. (2012). Targeting and Socio-Economic Impact of Microfinance, A Case Study of Pakistan (Working Paper 1433-02). Islamic Research and Training Institute.

Stauffenberg, D. V., et al. (2003). Performance Indicators for Microfinance Institutions, Technical Guide. Washington DC: Inter-American Development Bank.

Tamanni, L., and Liu, F. H. (2015, September). Islamic Microfinance Institutions, Pro-Poor or Profit?. Paper presented at the Inaugural Symposium on Islamic Finance, World Bank and Islamic Development Bank, Istanbul.

Tamanni, L., and Mukhlisin, M. (2013). Sakinah Finance, Solusi Mudah Mengatur Keuangan Keluarga Islami. Solo: Tinta Medina.

Tucker, M. (2001). Financial Performance of Selected Microfinance Institutions, Benchmarking Progress to Sustainability. Journal of Microfinance, Vol. 3(2): 107-123.

Widiarto, I., and Emrouznejad, A. (2015). Social and Financial Efficiency of Islamic Microfinance Institutions, A Data Development Analysis Application. Socio-Economic Planning Sciences, Vol. 50: 1-17.

World Bank. (2013). Inclusion Matters, The Foundation for Shared Prosperity (Advance edition). Washington DC: World Bank.

Yanah. (2014). Strategi Pengentasan Kemiskinan di Indonesia melalui Sinergi antara Bank Syariah dan BAZNAS. Jurnal Ekonomi, Vol. 2(3): 1-33.

Yunus, M. (2004). Grameen Bank, Microcredit, and Millenium Development Goals. Economic and Political Weekly, Vol. 39(36): 4077-4085.

Yuqing, C. (2007). Can Microfinance Change the Lives of the Poor in China? (Reuters Fellowship Paper). Oxford University.

Zada, N., and Saba, I. (2013). The Potential Use of Qard Hasan in Islamic Microfinance", ISRA International Journal of Islamic Finance, Vol. 5(2): 153162.

Zeller, Z., and Meyer, R. L. (2002).The Triangle of Microfinance, Financial Sustainability, Outreach and Impact. London: The John Hopkins University Press. 


\section{Appendix 1}

\section{Elements of Holistic Financial Inclusion, References}

\begin{tabular}{|c|c|}
\hline \multirow{2}{*}{ VARIABLE } & DEFINITION \\
\hline & REFERENCE \\
\hline \multicolumn{2}{|r|}{ 1. SOCIAL PROGRAM } \\
\hline \multirow{3}{*}{$\begin{array}{l}\text { Basic Needs } \\
\text { Fulfilment }\end{array}$} & Basic needs fulfilment refers to the provision of basic food, clothing and shelter \\
\hline & $\begin{array}{l}\text { to the needy (mustahiq) using social funds, especially zakat, which can be } \\
\text { provided by Baitul Maal (BM) of a BMT or collaboration between BM of a } \\
\text { BMT and other institution. }\end{array}$ \\
\hline & $\begin{array}{l}\text { Nazirwan (2015; p.27), IRTI (2014; p.19), S.Ali (2014; p.10), Obaidullah } \\
\text { and Khan (2008: p.17), Obaidullah (2008a: p.10,29), Beik and Arsyanti } \\
\text { (2015; p.93) }\end{array}$ \\
\hline \multirow[t]{2}{*}{ Bailout Debt } & $\begin{array}{l}\text { Bailout debt refers to the provision of bail-out fund to mustahiq debtors } \\
\text { (gharimin) who could not repay their debt, especially to loan sharks, using zakat } \\
\text { funds, which can be provided by BM of a BMT or collaboration between BM of } \\
\text { a BMT and other institution. }\end{array}$ \\
\hline & $\begin{array}{l}\text { Kahf (2002: p.40,64), Obaidullah (2008: p.27), IRTI (2014; p.41), Bremer } \\
(2014 ; \text { p.16,36) }\end{array}$ \\
\hline \multirow[t]{2}{*}{ Health Care } & $\begin{array}{l}\text { Health care services refer to the provision of various health care services with no } \\
\text { or minimum charge to the needy (mustahiq), which can be provided by BM of } \\
B M T \text { or collaboration between BM of BMT and other institution. }\end{array}$ \\
\hline & $\begin{array}{l}\text { Saha (2011; p.2), Alam and Getubig (2010; p.82), Yanah (2014; p.15), } \\
\text { Nazirwan (2015; p.27), Ascarya (2014; p.16). }\end{array}$ \\
\hline \multirow[t]{2}{*}{ Social Services } & $\begin{array}{l}\text { Social services refers to the provision of various social services, such as death, } \\
\text { accident, etc., to the needy (mustahiq), which can be provided by BM of a BMT } \\
\text { or collaboration between BM of a BMT and other institution. }\end{array}$ \\
\hline & $\begin{array}{l}\text { Ismail and Possumah (2014; p12), Nazirwan (2015; p.262), Yanah (2014; } \\
\text { p.17,20,22) }\end{array}$ \\
\hline \multirow[t]{2}{*}{$\begin{array}{l}\text { Motivational } \\
\text { Support }\end{array}$} & $\begin{array}{l}\text { Motivational support refers to provision of moral and consultative support to } \\
\text { mustahiq to motivate and lift their spirit of good life (include religiously). }\end{array}$ \\
\hline & $\begin{array}{l}\text { Hadisumarto and Ismail (2010; p.71,72), Obaidullah (2008: p.19), } \\
\text { Obaidullah and Khan (2002; p.3); Kahf (2002: p.64) }\end{array}$ \\
\hline \multirow[t]{2}{*}{ Halaqah } & $\begin{array}{l}\text { Halaqah refers to gathering for Islamic studies conducted or organized by BMT } \\
\text { for its BM or BT members to improve their religious life. }\end{array}$ \\
\hline & $\begin{array}{l}\text { Nazirwan (2015; p.209), Obaidullah (2008: p.19); Obaidullah and Khan } \\
\text { (2008: p. 29), Ahmed (2002: p.57) }\end{array}$ \\
\hline \multirow[t]{2}{*}{$\begin{array}{l}\text { Basic Education } \\
\text { Scholarship }\end{array}$} & $\begin{array}{l}\text { Basic Education scholarship refers to provision of basic education scholarship } \\
\text { for children of poor families (mustahiq) provided or organized by BM of BMT. }\end{array}$ \\
\hline & $\begin{array}{l}\text { Yanah (2014; p.18), Hassan (2010; p.275), Ahmed (2004; p.63,82,114), } \\
\text { Obaidullah (2008a; p.28) }\end{array}$ \\
\hline & 2. DEVELOPMENT PROGRAM \\
\hline Regular Meeting & $\begin{array}{l}\text { Regular meeting refers to scheduled meeting (weekly, etc.) where BMT } \\
\text { representative meet groups of BMT members for business transactions (such as, } \\
\text { disbursement, collection, savings and business consultation) and non-business } \\
\text { activities (such as, various trainings, teachings, halaqah and social activities). }\end{array}$ \\
\hline
\end{tabular}


Nazirwan (2015; p.229), Obaidullah (2008: p.16, p.64), Ahmed (2002: p.32, p.42), Alam and Gedubig (2010; p.40,41), Ledgerwood (1999; p.84,85), Ascarya (2014; p.16)

Savings Program Savings program refers to BMT program that requires its members to make regular (daily, weekly, etc.) small amount of savings to discipline members in managing their wealth and cash flow.

Adnan and Ajija (2015; p.176), Obaidullah (2008; p.17), Alam and Getubig (2010; p.22), Armendariz and Morduch (2010: p.16), Ascarya (2014; p.16)

Skills training Skills training refers to provision of various technical skills training/workshop by BMT or other institutions for BMT members to improve their skills in operating their micro businesses.

Hoque, et al. (2015; p.15), M.Ali (2014: p.12), IRTI (2014; p.19), Obaidullah (2008: p.29, p.60), Ahmed (2004; p.108), Kahf (2002: p.62), Ledgerwood (1999; p.79), Ascarya (2014; p.16), Bremer (2014; p.16)

Family Financial It is a training/workshop by BMT or other institutions for BMT members Management intended to provide foundational understanding of family financial Training management for planning and protecting family's financial future.

Tamanni and Mukhlisin (2013: p.54), Obaidullah (2008;p.10), Muslim (2006: Hadith No.562, p.1361), An-Nawawi (2001: Hadith No.2984, p.199)

Micro Enterprise It is a training/workshop by BMT or other institutions for BMT members Management intended to provide basic skills to manage micro enterprise, such as how to plan, Training organize, command, coordinate, and control micro business.

Hoque, et al. (2015; p.15), Obaidullah (2008: p.2 and p.10), Ahmed (2002: p.57), Kahf (2002: p.62), Ledgerwood (1999; p.79)

Micro Enterprise It is a training/workshop by BMT or other institutions for BMT members Marketing intended to provide basic skills to market and sell their ME products or services Training to their customers, which could include online marketing and business networking.

Edgcomb (2001; p.36), Hadi sumarto and Ismail (2010: p. 71), Ledgerwood (1999; p.63,79) Kahf (2002: p.62), Obaidullah (2008; p.34), MFC, et al. $(2007 ; 60)$

Qardh Financing Qardh financing refers to provision of benevolent financing (with no fee, margin or interest) by BMT to its mustahiq members to start their own micro businesses.

Hadisumarto and Ismail (2010: p. 67), Zada and Saba (2013: p.155), Obaidullah (2008: p.64), Ahmed (2002: p.38), Ahmed (2004: p.130), Mohieldin, et al. (2012: p.66), M.Ali (2014; p.11)

\section{FINANCING PROGRAM}

Easy Access Easy access refers to provision of financing to BMT members/customers with minimum or no hassles, obstacles or barriers, and reflected with fast process.

Demirgüç-Kunt et al. (2008: p.28), Bank Indonesia (2014; p.9), Obaidullah (2008: p.62), CSFI (2014; p.42), GPFI (2012: p.1), ADBI (2014: p.45), Ascarya (2014; p.16), Hoque, et al. (2014; p.139)

Simplicity Simplicity refers to provision of financing to BMT members/customers with no complicated requirements and process.

Nazirwan (2015; p.243,270), Campion (2000; p.13), M.Ali (2014; p.1), 


\begin{tabular}{|c|c|}
\hline & GPFI (2012: p.4), Ledgerwood (1999; p.66), Ascarya (2014; p.16) \\
\hline \multirow[t]{2}{*}{ Affordable } & $\begin{array}{l}\text { Affordable refers to provision of financing to BMT members/customers with } \\
\text { affordable total costs of financing, including margin, administration fee, } \\
\text { provision, micro takaful, etc. }\end{array}$ \\
\hline & Demirgüç-Kunt, et al. (2008: p.22,43), Littlefield, et al. (2003; p.2) \\
\hline \multirow{3}{*}{$\begin{array}{l}\text { Flexible } \\
\text { Collateral }\end{array}$} & Flexible collateral refers to provision of financing to BMT members/customers \\
\hline & $\begin{array}{l}\text { without formal collateral requirements, instead it uses other forms of simple or } \\
\text { no collateral, such as joint responsibility in group lending and cash collateral } \\
\text { through compulsory savings. }\end{array}$ \\
\hline & $\begin{array}{l}\text { Ledgerwood (1999; p.72,137,138), Nazirwan (2015; p.270), Yuqing (2007; } \\
\text { p.14), Demirgüç-Kunt et al (2008: p.120), Karpowicz (2014: p.6), GPFI } \\
\text { (2012: p.4), Obaidullah (2008: p.6), Kahf (2002: p.64) }\end{array}$ \\
\hline \multirow[t]{2}{*}{ Pick-Up Services } & $\begin{array}{l}\text { Pick-up services refer to provision of financing to BMT members/customers } \\
\text { where the account officer of BMT who visit the members/customers to do all } \\
\text { business and non-business activities, especially in collection (daily, weekly, } \\
\text { etc.). }\end{array}$ \\
\hline & $\begin{array}{l}\text { Nazirwan (2015; p.207,269), Ascarya and Cahyono (2011: p.13); } \\
\text { Armendariz and Morduch (2010: p.97); Rhyne (2009: p.164), Ascarya } \\
\text { (2014; p.16) }\end{array}$ \\
\hline \multirow[t]{2}{*}{ Risk Mitigation } & $\begin{array}{l}\text { Risk mitigation refers to various common and unique ways to mitigate risks of } \\
\text { financing to BMT members/customers, such as frequent (daily, weekly, etc.) } \\
\text { visit and collection, implanting Islamic values (especially in business dealings), } \\
\text { and cash collateral. }\end{array}$ \\
\hline & $\begin{array}{l}\text { Nazirwan (2015; p.250), Hadisumarto and Ismail (2010: p.71), Yuqing } \\
\text { (2007; p.13,14). Campion (2000; p.10), CSFI (2014; p.34), Ahmed (2002; } \\
\text { p.39),M.Ali (2014; p.16), Iqbal and Mirakhor (2012; p.36), Obaidullah } \\
\text { (2008: p.10), Ascarya (2014; p.16) }\end{array}$ \\
\hline \multirow[t]{2}{*}{ Monitoring } & $\begin{array}{l}\text { Monitoring refers to various ways done by BMT to determine financing of } \\
\text { members/ customers soundness and provide early warning signs of potential } \\
\text { non-performing financing, such as frequent (daily, weekly, etc.) visit. }\end{array}$ \\
\hline & $\begin{array}{l}\text { Nazirwan (2015; p.245), Hadisumarto and Ismail (2010: p. 70), Ahmed } \\
\text { (2004: p. 113), Ahmed (2002: p.56), Kahf (2002: p.63) }\end{array}$ \\
\hline & 4. Islamic MICROFINANCE SERVICES \\
\hline \multirow[t]{2}{*}{ Micro Financing } & $\begin{array}{l}\text { Micro financing refers to various micro financing facilities provided by BMT } \\
\text { for its members/customers, for various purposes using various Islamic modes of } \\
\text { finance. }\end{array}$ \\
\hline & $\begin{array}{l}\text { Nazirwan (2015; p.241), Obaidullah and Khan (2008; p.11), S.Ali (2014: } \\
\text { p.12), M.Ali (2014; p.2), Bogan, et al. (2007; p.2), Obaidullah (2008: p.63), } \\
\text { Kahf (2002: p.61), Littlefield, et al. (2003; p.1), }\end{array}$ \\
\hline \multirow[t]{2}{*}{ Micro Savings } & $\begin{array}{l}\text { Micro savings refers to various micro savings products offered by BMT for its } \\
\text { members/customers, including saving deposits, time deposits and savings for } \\
\text { certain purposes, such as education and IedulQurban. }\end{array}$ \\
\hline & $\begin{array}{l}\text { Nazirwan (2015; p.228), Obaidullah (2008; p.44), Obaidullah and Khan } \\
\text { (2008; p.11), S.Ali (2014: p.12), M.Ali (2014; p.2), Bank Indonesia (2014: } \\
\text { p.4), CSFI (2014; p.42), Bogan, et al. (2007; p.2), Ahmed (2002: p.57), } \\
\text { Kahf (2002: p.64), Littlefield, et al. (2003; p.1) }\end{array}$ \\
\hline Micro Takaful & $\begin{array}{l}\text { Micro takaful refers to micro Islamic insurance to provide protection of BMT's } \\
\text { financing against certain risks of non-performing financing, such as death of }\end{array}$ \\
\hline
\end{tabular}




\begin{tabular}{|c|c|}
\hline & borrowers. \\
\hline & $\begin{array}{l}\text { Khadijah, et al. (2013; p.75), Obaidullah and Khan (2008; p.12), ADBI } \\
\text { (2014: p.41), S.Ali (2014: p.12), M.Ali (2014; p.2), Bank Indonesia (2014: } \\
\text { p.4), Cull, et al (2014: p.5); Mohieldin, et al. (2012: p.74); Obaidullah } \\
\text { (2008: p.64); Bogan, et al. (2007; p.2), Ahmed (2004: p.130), Ledgerwood } \\
\text { (1999; p.74), Littlefield, et al. (2003; p.1) }\end{array}$ \\
\hline Micro Transfer & $\begin{array}{l}\text { Micro transfer refers to financial service which provides remittance services for } \\
\text { BMT members/customers who need to transfer money for business or personal } \\
\text { purposes. }\end{array}$ \\
\hline & $\begin{array}{l}\text { M.Ali (2014: p.2), GPFI (2012: p.4), Obaidullah (2008: p.4), Obaidullah } \\
\text { and Khan (2008: p.12), Ahmed (2002: p.41), Littlefield, et al. (2003; p.1) }\end{array}$ \\
\hline $\begin{array}{l}\text { Micro Pension } \\
\text { Fund }\end{array}$ & $\begin{array}{l}\text { Micro pension fund refers to financial service which provides retirement plans } \\
\text { for BMT members/customers. }\end{array}$ \\
\hline & $\begin{array}{l}\text { Njuguna (2012; p.82), Yunus (2004; p.4079); Rhyne (2009: p.33); } \\
\text { Obaidullah and Khan (2008: p.28); Reyes (2010; p.2), Littlefield, et al. } \\
\text { (2003; p.1), Ismail and Possumah (2014; p.11) }\end{array}$ \\
\hline $\begin{array}{l}\text { Emergency } \\
\text { Financing }\end{array}$ & $\begin{array}{l}\text { Emergency financing refers to provision of financing to BMT's } \\
\text { members/customers facing emergency situations, such as sickness or injury, } \\
\text { theft, and the loss of employment. }\end{array}$ \\
\hline & $\begin{array}{l}\text { Obaidullah and Khan (2008: p.11,12), Obaidullah (2008a; p.2), CSFI } \\
\text { (2014; p.39), Khan, et al. (2007; p.21) }\end{array}$ \\
\hline Bill Payment & $\begin{array}{l}\text { Bill Payment refers to financial service which is provided for BMT's } \\
\text { members/customers to pay their bills, such as electricity, phone and water bills. }\end{array}$ \\
\hline & $\begin{array}{l}\text { Nazirwan (2015; p.227), Demirgüç-Kunt, et al (2008: p.43,112), } \\
\text { Ledgerwood (1999; p.66), Rhyne (2008; p.37) }\end{array}$ \\
\hline & 5. OUTREACH \\
\hline embers & $\begin{array}{l}\text { Number of members refer to the total member, including full member and } \\
\text { potential member of BMT, which measures the breadth of outreach to the poor. }\end{array}$ \\
\hline & $\begin{array}{l}\text { Nazirwan }(2015 ; 205) \text {, Rosenberg (2009; p.3), Alaeddin and Anwar (2012; } \\
\text { p.18), Cokro and Ismail (2008; p.20), Charitonenko and Afwan (2003; } \\
\text { p.30) }\end{array}$ \\
\hline Total Deposits & $\begin{array}{l}\text { Total deposits refer to the total amount of deposits (in financial term) collected } \\
\text { by BMT from its members/customers. }\end{array}$ \\
\hline & $\begin{array}{l}\text { Natilson and Bruett (2001; p.18), Demirgüç-Kunt, et al (2008: p.33,34), } \\
\text { Ascarya (2014; p.16) }\end{array}$ \\
\hline No. of Borrowers & $\begin{array}{l}\text { Number of borrowers refer to the total BMT's members/customers who obtain } \\
\text { various types of financing for various purposes, which measures the breadth of } \\
\text { outreach to the poor. }\end{array}$ \\
\hline & $\begin{array}{l}\text { Rosenberg (2009; p.3), Alaeddin and Anwar (2012; p.18), Cokro and } \\
\text { Ismail (2008; 19), Natilson and Bruett (2001; p.31), Widiarto and } \\
\text { Emrouznejad (2015; p.2), Ascarya (2014; p.16) }\end{array}$ \\
\hline Total Financing & $\begin{array}{l}\text { Total financing refers to the total amount of various micro financing extended } \\
\text { by BMT to its members/customers. }\end{array}$ \\
\hline & $\begin{array}{l}\text { Ledgerwood (1999; p.226), Demirgüç-Kunt, et al (2008: p.36,63), Ascarya } \\
\text { (2014; p.16) }\end{array}$ \\
\hline Average & Average financing refers to the mean or mode of financing amount extended by \\
\hline Financing & BMT to its members/borrowers. \\
\hline & Rosenberg (2009; p.4), Widiarto and Emrouznejad (2015; p.2), Alam and \\
\hline
\end{tabular}




\begin{tabular}{|c|c|}
\hline & $\begin{array}{l}\text { Getubig (2010: p.131), Alaedin and Anwar (2012; p.18), Ascarya and } \\
\text { Sanrego (2007: p.17), Charitonenko and Afwan (2003; p.32), } \\
\text { Ledgerwood (1999; p.226), Atnafu (2010; p.62), Ascarya (2014; p.16) }\end{array}$ \\
\hline \multirow[t]{2}{*}{ No. of Branches } & $\begin{array}{l}\text { Number of branch refers to the total number of branches owned by BMT to } \\
\text { expand its network and increase its breadth of outreach to the poor. }\end{array}$ \\
\hline & $\begin{array}{l}\text { Nazirwan (2015; p.257,271), Ledgerwood (1999; p.124), Naceur, et al. } \\
\text { (2015; p.12), Demirgüç-Kunt, et al. (2008; p.10), Ascarya (2014; p.16) }\end{array}$ \\
\hline \multirow[t]{2}{*}{ Area Coverage } & $\begin{array}{l}\text { Area coverage refers to geographic area of business covered by a BMT with its } \\
\text { branches, which could be very narrow in one rural area or very wide to cover } \\
\text { the whole country. }\end{array}$ \\
\hline & $\begin{array}{l}\text { Ledgerwood (1999; p.40), Natilson and Bruett (2001; p.31), Bank } \\
\text { Indonesia (2014: p.9), Demirgüç-Kunt, et al. (2008, p.125), Ascarya (2014; } \\
\text { p.16) }\end{array}$ \\
\hline \multicolumn{2}{|r|}{ 6. SUSTAINABILITY } \\
\hline \multirow[t]{2}{*}{$\begin{array}{l}\text { Funding } \\
\text { Independent }\end{array}$} & $\begin{array}{l}\text { Funding independent measures the independency of BMT in meeting its } \\
\text { financing needs of funding by collecting various types of deposits from its own } \\
\text { members or potential members, and at the same time free from external funding } \\
\text { (donors, government and other financial institutions). }\end{array}$ \\
\hline & $\begin{array}{l}\text { Rusydiana and Devi (2013; p.53), Nazirwan (2015; p.269), Rokhman } \\
\text { (2013; p.184), Ascarya and Cahyono (2011; p.14), Ascarya (2014; p.16) }\end{array}$ \\
\hline \multirow[t]{2}{*}{ Profitability } & $\begin{array}{l}\text { Profitability measures a BMT's net income in relation to the structure of its } \\
\text { balance sheet which can be measured by Return on Assets (ROA) and Return } \\
\text { on Equity (ROE). }\end{array}$ \\
\hline & $\begin{array}{l}\text { Ledgerwood (1999; p.220), Nazirwan (2015; p.218), Juwaini, et al. (2010; } \\
\text { p.14), Bank Indonesia (2012; p.182,187), APO (2006; p.37), Stauffenberg } \\
\text { (2003; p.3), Ahmed (2002; p.47), CGAP (2003; p.12), Rosenberg (2009; } \\
\text { p.8), Farooq and Khan (2014; p.28) }\end{array}$ \\
\hline \multirow[t]{2}{*}{$\begin{array}{l}\text { Operational } \\
\text { Efficiency }\end{array}$} & $\begin{array}{l}\text { Operational efficiency measures the ratio between the input to run business } \\
\text { operations and the output gained the business which can be measured by the } \\
\text { ratio of operational cost to operational income. }\end{array}$ \\
\hline & $\begin{array}{l}\text { Bank Indonesia (2012; p.185), Alfriska and Haryani (2011; p.92), Seibel } \\
\text { (2012; p.53,68), Ismail and Possumah (2012; p.2) }\end{array}$ \\
\hline \multirow[t]{2}{*}{ Fund Efficiency } & $\begin{array}{l}\text { Fund efficiency measures how efficient a BMT intermediate between depositors } \\
\text { and borrowers, which can be measured by net margin between margin of } \\
\text { financing and margin of funding. The lower the net margin, the more efficient } \\
\text { BMT. }\end{array}$ \\
\hline & $\begin{array}{l}\text { Atnafu (2010; p.43), Microrate (2014; p.32), Beck and Hesse (2006; p.23), } \\
\text { Ascarya and Cahyono (2011; p.14), Ascarya (2014; p.16) }\end{array}$ \\
\hline \multirow[t]{2}{*}{ Staff Productivity } & $\begin{array}{l}\text { Staff productivity measures the productivity of the employees in reaching the } \\
\text { customers (depositors and borrowers) which can be measured by customers to } \\
\text { employee ratio. }\end{array}$ \\
\hline & $\begin{array}{l}\text { Ahmed (2002; p.47), Ledgerwood (1999; p.212), Ascarya and Cahyono } \\
\text { (2011; p.5); Farooq and Khan (2014; p. 23), Ascarya (2014; p.16), Juwaini, } \\
\text { et al. (2010; p.14) }\end{array}$ \\
\hline \multirow[t]{2}{*}{$\begin{array}{l}\text { Financing } \\
\text { Performance }\end{array}$} & $\begin{array}{l}\text { Financing performance measures the quality of BMT's financing which can be } \\
\text { measured by the ratio of non-performing financing to total financing. }\end{array}$ \\
\hline & $\begin{array}{l}\text { Nazirwan (2015; p.248), Hadisumarto and Ismail (2010; p.68), Microrate } \\
\text { (2014; p.9,12), Tucker (2001; p.118); Obaidullah (2008; p.23), Rosenberg }\end{array}$ \\
\hline
\end{tabular}




\begin{tabular}{|c|c|}
\hline & (2009; p.6), Seibel (2012; p.39) \\
\hline \multirow[t]{2}{*}{ Asset Growth } & Asset growth measures the growth of BMT's assets annually. \\
\hline & $\begin{array}{l}\text { Nazirwan (2015; p.213), Ledgerwood (1999; p.231), Rosenberg (2009, } \\
\text { p.11), Cokro and Ismail (2008; p.3), Natilson and Bruett (2001; p.32), } \\
\text { Evans and Branch (2002; p.10), Bogan, et al. (2007; p.21) }\end{array}$ \\
\hline \multicolumn{2}{|r|}{ 7. ECONOMIC IMPACT } \\
\hline \multirow[t]{2}{*}{$\begin{array}{l}\text { Consumption } \\
\text { Smoothing }\end{array}$} & $\begin{array}{l}\text { Consumption smoothing refers to a stable path of consumption desired by the } \\
\text { (poor) people, which can be proxied by the percentage of performing qardh } \\
\text { (benevolent loan) recipients. }\end{array}$ \\
\hline & $\begin{array}{l}\text { Khandker (2005; p.21), Demirgüç-Kunt, et al (2008: p.105,111), Demirgüç- } \\
\text { Kunt and Klapper (2013; p.284), Obaidullah (2008: p.11), Littlefield, et al. } \\
\text { (2003; p.2,3), Ascarya (2014; p.8) }\end{array}$ \\
\hline \multirow[t]{2}{*}{ Income Increase } & $\begin{array}{l}\text { Income increase refers to the increase in average income of BMT's } \\
\text { members/borrowers, which can be estimated by the percentage of qardh and } \\
\text { commercial financing borrowers who generate more income. }\end{array}$ \\
\hline & $\begin{array}{l}\text { Cokro and Ismail (2008; p.21), Hadisumarto and Ismail (2010: p. 69), } \\
\text { M.Ali (2014: p.2), Littlefield, et al. (2003; p.1), Fehr and Hishigsuren } \\
\text { (2004; p.9), Obaidullah (2008: p.59), Littlefield, et al. (2003; p.2), Ascarya } \\
\text { (2014; p.16) }\end{array}$ \\
\hline \multirow[t]{2}{*}{ Asset Building } & $\begin{array}{l}\text { Asset building refers to the increase in total assets of BMT's } \\
\text { members/borrowers, which can be estimated by the percentage of qardh and } \\
\text { commercial borrowers who accumulate more assets. }\end{array}$ \\
\hline & $\begin{array}{l}\text { Fehr and Hishigsuren (2004; p.9), Khandker (2005; p.4), Hadisumarto } \\
\text { and Ismail (2010: p. 71), Ahmed (2002: p.53), M.Ali (2014: p.2), } \\
\text { Littlefield, et al. (2003; p.1,2), IFAD (2006; p.90), Ascarya (2014; p.8) }\end{array}$ \\
\hline \multirow[t]{2}{*}{$\begin{array}{l}\text { Poverty } \\
\text { Alleviation }\end{array}$} & $\begin{array}{l}\text { Poverty alleviation refers to the ability of the poor to create wealth on } \\
\text { themselves to be self-sustained and successfully graduate from mustahiq status. }\end{array}$ \\
\hline & $\begin{array}{l}\text { Mohieldin, et al. (2012; p.76), Hadisumarto and Ismail (2010: p. 69), Kahf } \\
\text { (2002: p.64), Demirgüç-Kunt, et al (2008: p.107), Obaidullah (2008: } \\
\text { p.11,29), Ahmed (2002: p.57), Littlefield, et al. (2003; p.2), Ascarya (2014; } \\
\text { p.8), Nazirwan (2015; p.27) }\end{array}$ \\
\hline \multirow[t]{2}{*}{$\begin{array}{l}\text { Entrepreneurship } \\
\text { Improvement }\end{array}$} & Entrepreneurship improvement refers to the improvement of $B M T^{\prime}$ 's members/ \\
\hline & $\begin{array}{l}\text { Shirazi (2010; p.19), Hoque, et al. (2014; p.13), Obaidullah (2008: p.63), } \\
\text { M.Ali (2014: p.5) }\end{array}$ \\
\hline \multirow[t]{2}{*}{$\begin{array}{l}\text { Skill } \\
\text { Improvement }\end{array}$} & $\begin{array}{l}\text { Skill improvement refers to the improvement of BMT's members/borrowers in } \\
\text { their business skills, such as technical skill, managerial skill and marketing } \\
\text { skill. }\end{array}$ \\
\hline & $\begin{array}{l}\text { Cokro and Ismail (2008; p.4), Obaidullah (2008: p.63), Khandker (2005; } \\
\text { p.21) }\end{array}$ \\
\hline \multirow[t]{2}{*}{$\begin{array}{l}\text { Employment } \\
\text { Increase }\end{array}$} & $\begin{array}{l}\text { Employment increase refers to the increase of BMT's members/borrowers in } \\
\text { employing more workers for their expanding micro businesses. }\end{array}$ \\
\hline & $\begin{array}{l}\text { Cokro and Ismail (2014; p.21), Fehr and Hishigsuren (2004; p.9,10), } \\
\text { Ahmed (2002: p.53), Hadisumarto and Ismail (2010; p.65), Yuqing (2007; } \\
\text { p.18) }\end{array}$ \\
\hline \multicolumn{2}{|r|}{ 8. SOCIAL IMPACT } \\
\hline Mi & $\begin{array}{l}\text { Mindset change refers to the shift in the way of thinking of BMT's } \\
\text { members/customers, such as from zakat recipient to zakat payer, from un- }\end{array}$ \\
\hline
\end{tabular}


empowered to empowered, from short-term to long-term views, from poor to rich feeling, and from socially excluded to socially included.

Hadisumarto and Ismail (2010: p.71,72), Ahmed (2002; p.32), Obaidullah (2008; p.29)

Empowered Empowered refers to the feeling of BMT's members/customers who have improved their degree of autonomy and self-determination to act on their own authority.

Nazirwan (2015; p.165), Hadisumarto and Ismail (2010; p.71), OECD (2012; p.3), Littlefield, et al. (2003; p.2)

Health Health improvement refers to the improvement of BMT's members/customers Improvement and their families who become healthier.

Obaidullah (2008: p.2), Hadisumarto and Ismail (2010; p.65), Littlefield, et al. (2003; p.1,5), Ascarya (2014; p.8), Cokro and Ismail (2008; p.8)

Knowledge Knowledge improvement refers to the improvement of BMT's
Improvement members/customers in their general knowledge, business knowledge, and religious knowledge.

Hadisumarto and Ismail (2010; p.71), Jariya (2013; p.52), Alpay (2012 ;p.14), Ascarya (2014; p.8)

School School attendance refers to the improvement of family members of BMT's Attendance members/customers in school enrollment.

Demirgüç-Kunt, et al (2008: p.103), Hadisumarto and Ismail (2010; p.69), Khandker (2005; p.4), IFAD (2006; p.28,90), Littlefield, et al. (2003; p.2), Ascarya (2014; p.8), Cokro and Ismail (2008; p.25)

\begin{tabular}{ll}
\hline Social & $\begin{array}{l}\text { Social improvement refers to the improvement in the social life of BMT's } \\
\text { Improvement }\end{array}$ \\
\cline { 2 - 3 } & members/customers which improve their social inclusion. \\
& MFC, et al. (2007; p.4), Rahman (2013; p.12), S.Ali (2014; p.12), CSFI \\
& 2014; p.39) \\
\hline Religious & $\begin{array}{l}\text { Religious improvement refers to the improvement in the religiosity of BMT's } \\
\text { Improvement }\end{array}$ \\
\cline { 2 - 3 } & $\begin{array}{l}\text { Hadisumarto and Ismail (2010: p. 72), Rahman and Dean (2013; p.302), } \\
\text { Obaidullah (2008; p.19), Ahmed (2002: p.41), Ascarya (2014; p.8), Cokro } \\
\text { and Ismail (2008; p.25) }\end{array}$ \\
\end{tabular}

\section{Appendix 2}

Overall Practitioners Geometric Mean Results

\begin{tabular}{lcclcc}
\hline \multicolumn{1}{c}{ Name } & Limiting & $\begin{array}{c}\text { Normalized } \\
\text { By Cluster }\end{array}$ & Name & Limiting & $\begin{array}{c}\text { Normalized } \\
\text { By Cluster }\end{array}$ \\
\hline \multicolumn{5}{c}{ OBJECTIVE } & \\
\hline Faith & 0.029624 & 21.94 & Lineage & 0.021089 & 15.62 \\
\hline Life & 0.026151 & 19.37 & Wealth & 0.033188 & 24.58 \\
\hline Intellect & 0.024948 & 18.48 & & \\
\hline \multicolumn{7}{c}{ CRITERIA } \\
\hline Social Program & 0.011133 & 11.13 & Outreach & 0.009968 & 9.97 \\
\hline Development Program & 0.014043 & 14.04 & Sustainability & 0.01643 & 16.43 \\
\hline Financing Program & 0.013416 & 13.42 & Economic Impact & 0.011788 & 11.79 \\
\hline Islamic-MF Services & 0.012612 & 12.61 & Social Impact & 0.010612 & 10.61 \\
\hline
\end{tabular}




\begin{tabular}{|c|c|c|c|c|c|}
\hline \multicolumn{3}{|c|}{ SOCIAL PROGRAM } & \multicolumn{3}{|c|}{ DEVELOPMENT PROGRAM } \\
\hline Bailout Debt & 0.016054 & 2.10 & Regular Meeting & 0.016326 & 2.13 \\
\hline Basic-Needs Fulfilment & 0.015050 & 1.97 & Saving Program & 0.015962 & 2.09 \\
\hline Health Care & 0.013269 & 1.73 & Skill Training & 0.012971 & 1.70 \\
\hline Social Services & 0.013256 & 1.73 & $\begin{array}{l}\text { Fam.Fin.Mgt- } \\
\text { Training }\end{array}$ & 0.013616 & 1.78 \\
\hline Motivational Support & 0.011992 & 1.57 & ME Mgt-Training & 0.012819 & 1.68 \\
\hline Halaqah & 0.012655 & 1.65 & $\begin{array}{l}\text { ME Marketing } \\
\text { Training }\end{array}$ & 0.012289 & 1.61 \\
\hline Basic Edu. Scholarship & 0.012734 & 1.66 & Qardh Financing & 0.012336 & 1.61 \\
\hline \multicolumn{3}{|c|}{ FINANCING PROGRAM } & \multicolumn{3}{|c|}{ ISLAMIC MICROFINANCE SERVICES } \\
\hline Easy Access & 0.016173 & 2.11 & Micro Financing & 0.015536 & 2.03 \\
\hline Simplicity & 0.016317 & 2.13 & Micro Savings & 0.016318 & 2.13 \\
\hline Affordable & 0.012708 & 1.66 & Micro Takaful & 0.013740 & 1.80 \\
\hline Flexible Collateral & 0.012518 & 1.64 & Transfer & 0.012581 & 1.64 \\
\hline Pickup Service & 0.012727 & 1.66 & Micro Pension & 0.013471 & 1.76 \\
\hline Risk Mitigation & 0.012988 & 1.70 & $\begin{array}{l}\text { Emergency } \\
\text { Financing }\end{array}$ & 0.012783 & 1.67 \\
\hline Monitoring & 0.012607 & 1.65 & Bill Payments & 0.011247 & 1.47 \\
\hline \multicolumn{3}{|c|}{ OUTREACH } & \multicolumn{3}{|c|}{ SUSTAINABILITY } \\
\hline No. of Members & 0.014369 & 1.88 & $\begin{array}{l}\text { Funding } \\
\text { Independent }\end{array}$ & 0.015869 & 2.07 \\
\hline Total Deposits & 0.015689 & 2.05 & Profitability & 0.015090 & 1.97 \\
\hline No. of Borrowers & 0.012892 & 1.69 & $\begin{array}{l}\text { Operational } \\
\text { Efficiency }\end{array}$ & 0.014050 & 1.84 \\
\hline Total Financing & 0.013393 & 1.75 & Fund Efficiency & 0.012096 & 1.58 \\
\hline Average Financing & 0.013551 & 1.77 & Staff Efficiency & 0.012869 & 1.68 \\
\hline No. of Branches & 0.012375 & 1.62 & $\begin{array}{l}\text { Financing } \\
\text { Performance }\end{array}$ & 0.014081 & 1.84 \\
\hline Area Coverage & 0.012216 & 1.60 & Growth & 0.013339 & 1.74 \\
\hline \multicolumn{3}{|c|}{ ECONOMIC IMPACT } & \multicolumn{3}{|c|}{ SOCIAL IMPACT } \\
\hline $\begin{array}{l}\text { Consumption } \\
\text { Smoothing }\end{array}$ & 0.016136 & 2.11 & Mindset Change & 0.015608 & 2.04 \\
\hline Income Increase & 0.015931 & 2.08 & Empowered & 0.014719 & 1.92 \\
\hline Asset Building & 0.013042 & 1.70 & $\begin{array}{l}\text { Health } \\
\text { Improvement }\end{array}$ & 0.013381 & 1.75 \\
\hline Poverty Alleviation & 0.014040 & 1.84 & $\begin{array}{l}\text { Knowledge } \\
\text { Improvement }\end{array}$ & 0.013895 & 1.82 \\
\hline $\begin{array}{l}\text { Entrepreneurship } \\
\text { Improv. }\end{array}$ & 0.011656 & 1.52 & $\begin{array}{l}\text { School } \\
\text { Attendance }\end{array}$ & 0.013064 & 1.71 \\
\hline Skill Improvement & 0.011992 & 1.57 & $\begin{array}{l}\text { Social } \\
\text { Improvement }\end{array}$ & 0.011360 & 1.48 \\
\hline Employment Increase & 0.012509 & 1.64 & $\begin{array}{l}\text { Religious } \\
\text { Improvement }\end{array}$ & 0.012748 & 1.67 \\
\hline
\end{tabular}

